\title{
Anthropogenic impacts on recent decadal change in temperature extremes over China: relative roles of greenhouse gases and anthropogenic aerosols
}

Article

Accepted Version

Chen, W. and Dong, B. (2019) Anthropogenic impacts on recent decadal change in temperature extremes over China: relative roles of greenhouse gases and anthropogenic aerosols. Climate Dynamics, 52 (5-6). ISSN 0930-7575 doi: https://doi.org/10.1007/s00382-018-4342-9 Available at https://centaur.reading.ac.uk/78120/

It is advisable to refer to the publisher's version if you intend to cite from the work. See Guidance on citing.

To link to this article DOI: http://dx.doi.org/10.1007/s00382-018-4342-9

Publisher: Springer

All outputs in CentAUR are protected by Intellectual Property Rights law, including copyright law. Copyright and IPR is retained by the creators or other copyright holders. Terms and conditions for use of this material are defined in the End User Agreement. 


\section{CentAUR}

Central Archive at the University of Reading

Reading's research outputs online 
Anthropogenic impacts on recent decadal change in temperature extremes over China: relative roles of greenhouse gases and anthropogenic aerosols

\author{
Wei Chen ${ }^{1}$ and Buwen Dong ${ }^{2}$
}

1. State Key Laboratory of Numerical Modeling for Atmospheric Sciences and Geophysical Fluid Dynamics, Institute of Atmospheric Physics, Chinese Academy of Sciences, Beijing 100029

2. National Centre for Atmospheric Science-Climate, Department of Meteorology, University of Reading, Reading, UK

Corresponding author:

Wei Chen,

Institute of Atmospheric Physics,

Chinese Academy of Sciences,

P. O. Box 9804, Beijing 100029, China.

E-mail: chenwei@mail.iap.ac.cn 


\section{Abstract}

Observational analysis indicates significant changes in some temperature extremes over China across the mid-1990s. The decadal changes in hot extremes are

4 characterized as a rise in annual hottest day and night temperatures (TXx and TNx) and 5 an increase in frequencies of summer days (SU) and tropical night (TR). The decadal

6 changes in cold extremes are distinguished by a rise in annual coldest day and night 7 temperatures (TXn and TNn) and a decrease in frequencies of ice days (ID) and frost 8 days (FD). These decadal changes manifest not only over China as a whole, but also 9 over individual climate sub-regions. An atmosphere-ocean-mixed-layer coupled model forced by changes in

11 greenhouse gases (GHG) concentrations and anthropogenic aerosol (AA) emissions

12 realistically reproduces the general spatial patterns and magnitudes of observed changes

13 in both hot and cold extremes across the mid-1990s, suggesting a pronounced role of

14 anthropogenic changes in these observed decadal changes. Separately, changes in GHG

15 forcing lead to rise in TXx, TNx, TXn and TNn, increase in frequencies of SU and TR

16 and decrease in frequencies of ID and FD over China through increased Greenhouse

17 Effect with positive clear sky longwave radiation and play a dominant role in simulated

18 changes of both hot and cold extremes over China. The AA forcing changes tend to

19 cool Southern China and warm Northern China during summer via aerosol-radiation

20 interaction and AA-induced atmosphere-cloud feedback and therefore lead to some

21 weak increase in hot extremes over Northern China and decrease over Southeast China. 
22 Meanwhile, AA changes lead to warming over China during winter through cloud

23 feedbacks related to aerosol induced cooling over tropical Indian Ocean and western

24 tropical Pacific, and also induce changes in cold extremes the same sign as those

25 induced by GHG, but with weak magnitude.

26 Key words: hot temperature extremes; cold temperature extremes; China; decadal

27 change; the mid-1990s; greenhouse gases; anthropogenic aerosol

28 1. Introduction

Understanding of the changes in climate extremes and the underling drivers is important for human society, economies and ecosystems. In the last few decades,

31 temperature extremes exhibited robust changes at global and regional scales, with more

32 hot extremes and less cold extremes (e.g., Alexander et al. 2006; Donat et al. 2013).

33 The impacts of temperature extremes have highlighted the urgency of improved

34 understanding of their physical causes and to what extent they are manifested in a

35 warming world (e.g., Otto et al. 2012; Christidis et al. 2013; Perkins 2015).

36 China experienced record-breaking heat waves and temperature extremes that 37 imposed disastrous impacts on individuals and society (e.g., Yin et al. 2016; Zhou et al.

38 2016; Freychet et al. 2017). Such as the 2013 heat wave in Central and Eastern China

39 (Ma et al. 2017), the 2014 hot and dry summer over Northeast China (Wilcox et al.

40 2015) and the 2015 extreme hot summer over Western China (Sun et al. 2016). The

41 trend of continuous warming and increase in hot extremes over China might be 
associated with the global-scale warming (e.g., Wei et al. 2011). This warming trend and increase in hot temperature extremes can be reproduced by the future climate change scenario (Yao et al. 2012), implying the role of anthropogenic activity in increasing hot temperature extremes.

Previous attribution studies detected that anthropogenic activity, as a combined effects of greenhouse gases (GHG) concentrations and anthropogenic aerosol (AA) emissions, induces the changes in temperature extremes over China. Approximately $90 \%$ of the observed changes in hot extremes since mid-20th century may contributed by anthropogenic forcing (e.g., Wen et al. 2013; Yin et al. 2016). The summer mean temperature and temperature extremes in Eastern China can be increased by the anthropogenic influence (Sun et al. 2014). The direct impacts of changes in GHG concentrations and AA contribute to the 2014 hot and dry summer in Northeast China, beside SST anomaly (Wilcox et al. 2015). Both anthropogenic factors and atmospheric natural variability contributed to the 2013 mid-summer heat wave in Central and Eastern China (Ma et al. 2017).

Physically, the climate system warms in response to the increase in GHG concentrations, because the atmosphere traps more outgoing longwave radiation (e.g., Cubasch et al. 2001; Dong et al. 2009, 2017a). In addition, AA can affect the surface and atmospheric temperature by altering the radiative properties of clouds through aerosol-cloud interaction (Hansen et al. 1997; Stevens and Feingold 2009), and by scattering and absorbing the solar radiation directly through aerosol-radiation 
interaction. Additionally, remote AA emissions can impact on local temperature and

64 temperature extremes through changing dynamics. For example, the remote AA

65 emissions over Europe have a downstream extension impact on the temperature and

66 temperature extremes over East Asia (Dong et al. 2015, 2016). Besides anthropogenic

67 aerosol emissions, natural aerosol emissions can also influence climate dynamics (e.g.,

68 Yang et al., 2016, 2017).

69 The previous studies have highlighted external forcings, particularly anthropogenic

70 changes, play an important role in decadal changes of temperature extremes. However,

71 the relative individual contributions of changes in GHG concentrations and AA

72 emissions to the observed changes in temperature extremes are still not clear. Therefore,

73 the main aims of this work are to quantify the relative roles of changes in GHG and AA

74 forcing in shaping the changes in temperature extremes over China, and to understand

75 the physical processes responsible.

Despite the rapid development of attribution studies in climate extremes in recent

77 years (Stott et al. 2016), there is still no consensus about the best methodology for

78 attribution. One widely-used attribution approach relies on an atmospheric general

79 circulation model (AGCM) forced by prescribed sea surface temperatures (SSTs), with

80 and without anthropogenic influences (e.g., Christidis et al. 2013; Kamae et al. 2014;

81 Kim et al. 2015; Schaller et al. 2016). A potential limitation of these experiments is the

82 lack of explicit air-sea interaction, which causes an inconsistency in surface energy

83 fluxes and can limit a model's ability to accurately simulate natural climate variability 
84 (e.g., Barsugli and Battisti 1998; He and Soden 2016). Another ordinary attribution 85 method is bases on a coupled general circulation model (CGCM) with constant 86 emissions, which reaches equilibrium after a long integration (Bollasina et al. 2011; Li 87 and Ting 2016; Wang et al. 2012, 2013). The experiments in CGCMs with full ocean 88 dynamics have huge computational cost. Moreover, the CGCMs may exhibit significant 89 biases in the mean state, such as a large cold equatorial SST bias in Pacific (Vanniere 90 et al. 2012). Thus, replacing the three-dimension ocean GCM with an ocean mixed91 layer model would reduce the cost of the experiments, and have a smaller SST bias (due 92 to a prescribed flux correction), whilst also retaining intra-seasonal variability and 93 coupling between the atmosphere and the ocean. Therefore, this work is based on a set 94 of experiments using an atmosphere-ocean-mixed-layer couple model (Hirons et al. 95 2015; Tian et al. 2018).

96 The structure of this paper is organized as follows: Section 2 illustrates the 97 observed decadal changes in temperature extremes over China. The model and 98 experiments are described briefly in Section 3. Section 4 evaluates the simulated 99 changes in response to changes in GHG concentrations and AA emissions. Sections 5 100 and 6 illustrate the physical processes involved in the responses of hot and cold 101 extremes to changes in anthropogenic forcings, respectively. Conclusions are 102 summarized in Section 7. 


\section{Observed decadal changes in temperature extremes over China}

104

105

106

107

108

109

$110105^{\circ} \mathrm{E}$, and Southwestern China (SWC) with 88 stations south of $35^{\circ} \mathrm{N}$ and west of

$111105^{\circ} \mathrm{E}$. The distributions of these three sub-regions are shown in Fig. 2a. Also used are

112 the global land gridded climate extremes (GHCNDEX) based on the Global Historical

113 Climatology Network (GHCN)-Daily dataset from 1960 to 2011 (Donat et al. 2013).

114 The hot extremes indices are annual hottest day temperature (TXx), and warmest night

115 temperature (TNx), the frequency of summer days (SU, annual number of days when

$116 \operatorname{Tmax}>25^{\circ} \mathrm{C}$ ), and tropical night (TR, annual number of days when $\operatorname{Tmin}>20^{\circ} \mathrm{C}$ ). The

117 cold extremes indices are annual coldest day temperature (TXn), and coldest night 118 temperature (TNn), the frequency of ice days (ID, annual number of days when Tmax $119<0{ }^{\circ} \mathrm{C}$ ), and frost days (FD, annual number of days when $\left.\operatorname{Tmin}<0^{\circ} \mathrm{C}\right)$.

\subsection{Observed decadal changes since the mid-1990s}

Figure 1 illustrates the time evolution of the area averaged annual mean 
123 climatology, averaged over the whole time period. These time series clearly show the

124 abrupt changes in both hot and cold extremes since the mid-1990s. Therefore, the

125 decadal change in this study is compared between present day (PD) of 1994 2011 and

126 early period (EP) of 1964 1981. During summer, a rapid increase in TXx since the mid-

127 1990s occurs in China (Fig. 1a). The change in TXx anomaly during the PD relative to

128 the $\mathrm{EP}$ is $0.57^{\circ} \mathrm{C}$ in China station data, which is about two times as large as its

129 interannual variation of $0.27{ }^{\circ} \mathrm{C}$. This robust increase is also supported by the

130 GHCNDEX data with a change in TXx anomaly of $0.77^{\circ} \mathrm{C}$. Additionally, the increase

131 of TXx from the EP to the PD occurs in each sub-region over China, with a range of

132 changes from $0.40{ }^{\circ} \mathrm{C}$ to $0.76^{\circ} \mathrm{C}$. Moreover, accompanied with the increase of TXx, the

133 frequency of SU rises by 9 days over China (8 days in GHCNDEX data; Fig. 1c).

134 Similar to the increase of TXx, TNx also shows significant increase over China since

135 the mid-1990s (Fig. 1b). The change in TNx anomaly is $0.76{ }^{\circ} \mathrm{C}\left(0.96^{\circ} \mathrm{C}\right.$ in GHCNDEX

136 data). The remarkable decadal increase of $\mathrm{TNx}$ occurs in individual sub-regions over

137 China, with the greatest amplitude of $1.05^{\circ} \mathrm{C}$ over $\mathrm{NC}$ and the smallest amplitude of

$138 \quad 0.52{ }^{\circ} \mathrm{C}$ over SEC. The frequency of TR rises by 8 days in China (Fig. 1d), coinciding

139 with the increase of TNx.

140 During winter, the cold extremes also exhibit decadal changes since the mid-1990s,

141 being characterized as a rise in temperature and a decrease in frequency of cold days.

142 TXn anomaly increases by $1.48^{\circ} \mathrm{C}$ over China (Fig. 1e), being similar to the change of

$1431.45^{\circ} \mathrm{C}$ in GHCNDEX data. The increase of TXn manifests over three sub-regions with 
144 a range from $0.94{ }^{\circ} \mathrm{C}$ to $1.59^{\circ} \mathrm{C}$. As a result of the increase of TXn, the frequency of ID

145 is decreased by about 4 days over China (Fig. 1g). The decrease in ID is mainly over

$146 \mathrm{NC}$, with the magnitude of 8 days. Moreover, a robust increase in TNn appears since

147 the mid-1990s. The changes of TNn anomaly is $1.82{ }^{\circ} \mathrm{C}$ over China, being consistent

148 with $1.86{ }^{\circ} \mathrm{C}$ in GHCNDEX data (Fig. 1f). The greatest increase of TNn is over NC

$149\left(2.17^{\circ} \mathrm{C}\right)$. Additionally, the frequency of FD is decreased by about 10 days (Fig. 1h). It

150 is noted that the changes in cold extremes are larger than hot extremes. This is consistent

151 with stronger seasonal warming over northern hemisphere mid-latitudes in boreal

152 winter than in boreal summer in response to anthropogenic forcing (e. g., John et al.

153 2012; Dong et al. 2017b), which is related to the snow-albedo feedback (e.g., Stouffer

154 and Wetherald 2007; Rangwala et al. 2016).

155 The spatial patterns of changes in these temperature extremes during the PD

156 relative to the EP are illustrated in Fig. 2. The most important features of changes are

157 the increase in hot extremes and decrease in cold extremes over the most regions of

158 China although there are some spatial variations (Figs. 2b-i). For the hot extremes, the

159 changes in TXx and TNx show a large increase over NC with a magnitude of about

$1601.0 \sim 1.5^{\circ} \mathrm{C}$ (Figs. $2 \mathrm{~b}$ and $\mathrm{c}$ ). While the changes in the frequencies of SU and TR show

161 the increase in a large domain over SEC (Figs. 2d and e). For the cold extremes, the

162 TXn and TNn show a relatively uniform increase over China with a range of 1.5 2.5

$163{ }^{\circ} \mathrm{C}$ (Figs. $2 \mathrm{f}$ and $\mathrm{g}$ ). The frequencies of ID and FD show a decrease over the most regions

164 of China (Figs. $2 \mathrm{~h}$ and i). 
166 China since the mid-1990s. Questions come out naturally: what has caused these rapid

167 changes? Do the anthropogenic activities drive these changes? A set of experiments 168 using a coupled climate model are performed to assess contributions of changes in 169 anthropogenic forcings (GHG concentrations and AA emissions) to observed decadal 170 changes in temperature extremes over China since the mid-1990s, and to quantify the 171 relatively roles of individual forcing factors and to elucidate physical processes 172 involved.

173 3. Model and experiments design

174 The model used is an atmosphere-ocean-mixed-layer coupled model called 175 MetUM-GOML1 (Hirons et al. 2015). The atmospheric component is the Met Office 176 Unified Model (MetUM) at the fixed scientific configuration Global Atmosphere 3.0 177 (GA3.0; Arribas et al. 2011; Walters et al. 2011) with a horizontal resolution of $1.875^{\circ}$ 178 longitude and $1.25^{\circ}$ latitude.

179 The model includes earth system components such as an interactive tropospheric 180 aerosol scheme and the following aerosol: ammonium sulphate, mineral dust, sea salt,

181 fossil fuel black carbon, fossil fuel organic carbon, biomass burning aerosols, and 182 secondary organic (biogenic) aerosols. The direct radiative effect due to scattering and 183 absorption of radiation by all aerosol species is represented in the model. The semi184 direct effect, whereby aerosol absorption tends to change cloud formation by warming 185 the aerosol layer, is included implicitly (Walters et al. 2011). The parameterization of 
187 suggested a good performance in simulating aerosol properties and the detailed 188 description of this aspect has been documented in Bellouin et al. (2011). The modeled 189 sulphate aerosol surface concentrations, nitrate aerosol concentrations, carbonaceous 190 aerosol concentrations and total AODs are all compares well against observed 191 measurements. Moreover, the model reproduced the known pattern of AOD, with 192 industrial pollution in North America, Europe, and Asia, biomass burning aerosols in 193 Central Africa and South America, and mineral dust transport across the Atlantic and 194 Arabian Sea. The eastward gradient in AOD in North America and China is well 195 reproduced.

196 The oceanic component is a Multi-Column K Profile Parameterization (MC-KPP)

197 mixed-layer ocean model. The atmospheric and oceanic components are coupled every

198 three hours. The air-sea coupling is limited by the maximum extent of a seasonally

199 varying sea ice climatology (Hirons et al. 2015). In the uncoupled region of MetUM-

200 GOML1, the atmosphere is forced by the repeating mean annual cycle of SST and sea 201 ice extent (SIE) from the Met Office HadISST data set (Rayner et al. 2003). The 202 horizontal resolution of MC-KPP is the same as the MetUM where it is coupled. The 203 MC-KPP columns have 100 vertical levels with a depth of $1000 \mathrm{~m}$. The vertical 204 discretization allows very high resolution (approximately one meter) in the upper ocean. 205 Since MC-KPP simulates only vertical mixing and does not include ocean dynamics, 206 climatological seasonal cycles of depth-varying temperature and salinity corrections are 
207 prescribed to represent the mean ocean advection and account for biases in atmospheric 208 surface fluxes.

209 Since the mid-1990s, there have been increased anthropogenic GHG 210 concentrations ( $14 \%$ increase in $\mathrm{CO}_{2}, 23 \%$ increase in $\mathrm{CH}_{4}$ and $7 \%$ increase in $\mathrm{N}_{2} \mathrm{O}$ ),

211 and significant changes in AA emissions. The changes in annual mean sulfur dioxide

212 emissions are characterized as decreases over Europe and North America and increases

213 over East and South Asia (Fig. 3).

214 As summarized in Table 1, a 12 year MetUM-GOML1 relaxation experiment (R0)

215 was firstly performed in which the MC-KPP profiles of temperature and salinity were

216 relaxed to a present day (PD; 1994 2011) ocean temperature and salinity climatology

217 derived from the Met Office ocean analysis (Smith and Murphy 2007). The relaxation

218 experiment used PD GHG and AA forcings (Lamarque et al. 2010, 2011). The daily

219 mean seasonal cycle of ocean temperature and salinity corrections from the coupled

220 relaxation experiment are then imposed in free-running coupled experiments. Four

221 other experiments are performed by using different forcings. These experiments

222 represent the early period (EP; 1964 1981), All Forcing present day (PDGA), GHG

223 forcing (PDG) and AA forcing (PDA) with no relaxation. All experiments are run for

22450 years and use the climatological PD sea ice extent from HadISST (Rayner et al.

225 2003). The last 45 years of each experiment are used for analysis. Using the same set

226 of experiments, Tian et al. (2018) has investigated the responses of the East Asian

227 summer monsoon. 
229 of experiments that include and exclude that forcing. The combined effect of changes

230 in both GHG and AA (hereafter All forcing) is the difference between PDGA and EP

231 experiment (PDGA - EP). The impact of changes in GHG concentrations (hereafter

232 GHG forcing) is the difference between PDG and EP (PDG - EP) and the impact of

233 changes in AA emissions (hereafter AA forcing) is the difference between PDA and EP

234 (PDA - EP).

\section{4. Model simulated changes in response to anthropogenic forcing}

The spatial distributions of changes in hot extremes in response to different

237 forcings are shown in Fig. 4. The model experiment in response to changes in All

238 forcing from the EP to the PD, not only reproduces the significant increase of hot

239 extremes over China, but also captures the generally spatial patterns of observed

240 changes (Figs. 4a-d). The increase of TXx and TNx in response to All forcing changes

241 exceeds $0.5^{\circ} \mathrm{C}$ over the most area of China (Figs. 4a and b), with a maximum center

242 over NC (exceed $1.0^{\circ} \mathrm{C}$ ), being consistent with observations (Figs. 2b and c). As a result,

243 the frequencies of SU and TR manifest a significant increase over China in response to

244 All forcing changes (Figs. 4c and d). The large increase domain is over SEC, which is

245 also seen in observations (Figs. $2 \mathrm{~d}$ and e). The similarities between the changes in

246 response to All forcing and observed changes indicate that the observed increase in hot

247 extremes over China since the mid-1990s is predominantly due to the anthropogenic 
GHG and AA changes.

Moreover, in response to the GHG forcing change, the hot extremes show a more or less uniform increase over China (Figs. 4e-h). The spatial pattern and magnitude of changes in hot extremes in response to GHG forcing changes are similar to those in response to All forcing changes, indicating that changes in GHG concentrations play a dominant role in the increase in hot extremes over China. Nevertheless, the role of changes in AA forcing in the hot extremes is relatively weak and shows a dipole pattern with increases in north and decreases in south (Figs. 4i-1). The increase in TXx and TNx, as well as the increase in the frequencies of $\mathrm{SU}$ and $\mathrm{TR}$, is shown over NC in response to changes in AA forcing, although the magnitude is weaker than that in response to changes in GHG forcing. However, the decrease in TXx, TNx and frequencies of SU and TR appears over SEC and SWC in response to changes in AA forcing.

In terms of the cold extremes, their responses to changes in different forcings are illustrated in Fig. 5. The rise in TXn and TNn and the decrease in the frequencies of ID and FD in response to All forcing changes coincide with observations (Figs. 5a-d). In response to changes in GHG forcing, the increase in TXn and TNn and the decrease in the frequencies of ID and FD are not only comparable to those in response to All forcing changes, but also consistent with those in observations (Figs. 5e-h), suggesting that GHG forcing changes play a vital role in the observed decadal changes of cold extremes. Additionally, AA forcing changes also contribute to changes in cold extreme (Figs. 5i1), particularly to the rise in TXn and TNn and decrease in frequencies of ID and FD 
over NC and SEC, although the magnitudes of changes are weaker than those in response to GHG forcing changes.

271 Quantitatively, the model simulated changes in response to All forcing changes 272 reproduce the observed changes in temperature extremes over China realistically, 273 although some extreme indices are overestimated a little bit. In response to All forcing 274 changes, the area averaged TXx (TNx) over China is $1.05^{\circ} \mathrm{C}\left(0.92{ }^{\circ} \mathrm{C}\right)$, which are 275 comparable to the observed changes of $0.58{ }^{\circ} \mathrm{C}\left(0.76{ }^{\circ} \mathrm{C}\right)$. The TXn and TNn averaged 276 over China in response to All forcing changes are $1.69^{\circ} \mathrm{C}$ and $1.45^{\circ} \mathrm{C}$, which are very 277 close to observed changes of $1.48{ }^{\circ} \mathrm{C}$ and $1.82{ }^{\circ} \mathrm{C}$.

Moreover, the agreement of model simulated magnitude of changes in extreme 279 indices with those in observations is not only over China as a whole, but also over 280 individual sub-regions. Figure 6 gives some area averaged changes in temperature 281 extreme indices over the three sub-regions for both observations and model simulated 282 responses. The area averaged changes in TXx in response to All forcing changes are 283 comparable to observations, although they are overestimated a little bit over NC and 284 SEC. The simulated TNx changes are also in good agreement with the observations, 285 particularly over NC. The change of TNx over NC in response to All forcing changes 286 is $1.07^{\circ} \mathrm{C}$, compared to the observed change of $1.05^{\circ} \mathrm{C}$. Additionally, the increases in 287 frequencies of SU and TR in response to All forcing changes are very similar to those 288 in observations in each sub-region. On the other side, the model simulated changes of 289 cold extremes in response to All forcing changes over the three sub-regions are in good 
$291\left(1.07^{\circ} \mathrm{C}\right)$ over SEC and $0.64^{\circ} \mathrm{C}\left(0.82^{\circ} \mathrm{C}\right)$ over SWC, which are very close to observed 292 changes of $1.59{ }^{\circ} \mathrm{C}\left(2.17^{\circ} \mathrm{C}\right)$ over $\mathrm{NC}, 1.52^{\circ} \mathrm{C}\left(1.59^{\circ} \mathrm{C}\right)$ over SEC and $0.94{ }^{\circ} \mathrm{C}(1.36$ $293{ }^{\circ} \mathrm{C}$ ) over SWC. The decrease of frequencies of ID and FD also coincides with 294 observations.

Separately, the model simulated response to GHG forcing changes exhibit increase

296 in hot extremes over all the three sub-regions. The magnitude of this increase in 297 response to GHG forcing changes is almost equal to that in response to All forcing 298 changes, indicating a dominant contribution of changes in GHG concentrations to the 299 simulated increase in hot extremes over China. On the contrary, the simulated responses 300 of hot extremes in response to AA forcing changes show positive value over NC but 301 negative value over SEC, which are consistent with the dipole pattern with increases in 302 north and decreases in south (Figs. 4i-1). In terms of cold extremes, the model simulated 303 increase in cold temperatures and decrease in frequencies of cold days result from the 304 combined effects of changes in both GHG concentrations and AA forcing. The 305 simulated change of TXn and TNn in response to GHG forcing changes is about two to 306 three times that in response to AA forcing changes. The simulated changes in TXn 307 (TNn) are $2.03{ }^{\circ} \mathrm{C}\left(1.08^{\circ} \mathrm{C}\right)$ over $\mathrm{NC}$ and $1.21{ }^{\circ} \mathrm{C}\left(1.71{ }^{\circ} \mathrm{C}\right)$ over SEC in response to 308 GHG forcing changes, in comparison to $0.76^{\circ} \mathrm{C}\left(0.55^{\circ} \mathrm{C}\right)$ over $\mathrm{NC}$ and $0.64{ }^{\circ} \mathrm{C}\left(0.5^{\circ} \mathrm{C}\right)$ 309 over SEC in response to AA forcing changes.

310 There is a nonlinearity for some extreme temperature changes in response to 
311 changes in GHG concentrations and AA forcing in model simulations, i.e., the sum of

312 responses to separate forcings is not equal to the response to changes in All forcings

313 together. This nonlinearity is weak over NC. The increase of extremes over NC in

314 response to changes in GHG forcing explains up to $75 \%$ of the $\mathrm{TNx}, 90 \%$ of the TXn

315 and $60 \%$ of the TNn increase in response to All forcing (assuming linearity). But the

316 nonlinearly is clearly shown for some temperature extremes over SEC (Fig. 6c), and ID

317 and FD over SWC (Fig. 6f). The nonlinearity of responses to different forcings has

318 noticed by previous studies (Feichter et al. 2004; Ming and Ramaswamy 2009;

319 Shiogama et al. 2012). They suggested that the nonlinear cloud response is likely the

320 source for this nonlinearity. The response of cloud water content and cloud radiative

321 effect have strong dependency in the combined forcing experiment than in either of the

322 individual forcing experiments. In our study, the large nonlinearity is over SEC, where

323 the water vapor content is high. The high humidity tends to increase the nonlinear cloud

324 response to the anthropogenic forcing. However, detailed discussion of this nonlinearity

325 is beyond the scope of this study.

326 The simulated response to changes in All forcing indicates that anthropogenic

327 changes play an important role in generating observed decadal changes in temperature

328 extremes. However, the responses to changes in GHG and AA show some different

329 characteristics. Model results indicate that GHG forcing changes tend to increase both

330 hot and cold extreme temperatures TXx, TNx, TXn, and TNn, increase frequency in

331 SU and TR, and decrease in ID and FD over China, while AA forcing changes are likely 
to warm NC and cool SEC during summer and induce surface warming over NC and

333 SEC during winter. The physical processes responsible for the changes in hot and cold

334 extremes in response to different forcings are discussed in next sections, respectively.

\section{Physical processes responsible for the decadal changes of hot extremes}

\subsection{Induces by GHG forcing changes}

The spatial patterns of summer mean changes for the key components of surface energy balance and related variables induced by changes in GHG forcing are illustrated in Fig. 7. The direct impact of the increase in GHG concentrations leads to an increase of clear sky downward longwave (LW) radiation of $0.94 \mathrm{~W} \mathrm{~m}^{-2}$ over China (Fig. 7a; as

341 expected for an increase in the Greenhouse Effect), although part of this increase would

342 be compensated by increase of upward surface LW radiation $\left(-0.49 \mathrm{~W} \mathrm{~m}^{-2}\right)$ since 343 surface warming (Fig. 7b). The net LW anomaly tends to reflect a balance between the 344 increase emission from the warmer surface (Fig. 7a) and the negative LW cloud 345 radiative effect (LW CRE; not shown), as a consequence of reduction in cloud cover 346 (Figs. 7c and d). The decrease in cloud cover over land is related to the decrease in 347 relative humidity (not shown) since specific humidity over land increases less 348 (reduction of evapotranspiration related to the $\mathrm{CO}_{2}$ physiological effect and constrained 349 by ocean warming) than specific humidity at saturation which increases with the 350 continental surface temperature following the Clausius-Clapeyron relationship (e.g., 351 Dong et al. 2009; Boé and Terray 2014). The reduction of cloud cover and decrease of 
352 relative humidity, being likely due to the surface warming, lead to positive shortwave

353 cloud radiative effect (SW CRE; with the value of $1.62 \mathrm{~W} \mathrm{~m}^{-2}$; Fig. 7e) and positive net 354 surface shortwave (SW) radiation (with the value of $0.95 \mathrm{~W} \mathrm{~m}^{-2}$; Fig. $7 \mathrm{f}$ ) over the most 355 part of China, which in turn have a positive feedback on surface warming. In summary, 356 it is the increased Greenhouse Effect that induces the increase in hot extremes over 357 China, with increase of the net downward clear sky LW radiation, in response to GHG 358 forcing changes. Moreover, the increase of net surface SW radiation related to positive 359 SW CRE, being associated with the decrease of cloud cover, has a positive feedback 360 with the surface warming due to the increase of GHG concentrations, which also 361 contributes to the increase of hot extremes over China.

\section{$362 \quad 5.2$ Induced by AA forcing changes}

The spatial distributions of the summer mean changes for the key components of

364 surface energy balance and related variables induced by changes in AA emissions are

365 illustrated in Fig. 8. Changes in aerosol optical depth (AOD) indicate a decrease over 366 Europe and an increase over East Asia and South Asia (Fig. 8a). Local increase of AOD over East Asia leads to decrease of net clear sky SW radiation $\left(-3.36 \mathrm{~W} \mathrm{~m}^{-2}\right)$ over China through aerosol-radiation interactions (Fig. 8b). However, the SW CRE changes show

369 positive anomaly, particularly over $\mathrm{NC}$ with a magnitude of $1.22 \mathrm{~W} \mathrm{~m}^{-2}$ (Fig. 8c). This 370 positive SW CRE warms the surface and leads to increase in hot extremes over NC 371 while the decrease of net surface SW radiation through AA induced net clear sky SW 372 radiation change cools the surface and leads to decrease in hot extremes over SEC. The 
373 positive SW CRE over NC is induced by the decrease of cloud cover (Fig. 8d), which

374 is related to the decrease of soil moisture (Fig. 8d) and water vapor in the atmosphere

375 (Fig. 8f). This is consistent with Tian et al. (2018), who suggested a drying over NC

376 related to a weakening of East Asian summer monsoon (EASM) in response to AA

377 forcing changes. The weakening of EASM is associated with weaker moisture transport

378 convergence and reduced precipitation (not shown), soil moisture (Fig. 8e) and

379 evaporation (not shown) over NC, leading to decrease in water vapor in the atmosphere

380 (Fig. 8f), which in turn gives rise to the positive SW CRE, as a consequence of decrease

381 in cloud cover. In summary, direct impact of changes in AA forcing induces a decrease

382 in clear sky SW radiation, which results in surface cooling over SEC and SWC.

383 However, the positive SW CRE and reduced upward latent heat flux (not shown),

384 induced by decrease of cloud cover related to reduction of precipitation over NC and

385 decrease of soil moisture, tend to warm the surface and contribute to increase in hot

386 extremes over NC.

387 6. Physical processes responsible for the decadal changes of cold extremes

$388 \quad 6.1$ Induces by GHG forcing changes

389 Figure 9 is the spatial distributions of the winter mean changes for the key

390 components of surface energy balance and related variables induced by changes in

391 GHG concentrations. The downward clear sky LW radiation is increased over southern

392 part of China with the value of $0.66 \mathrm{~W} \mathrm{~m}^{-2}$ (Fig. 9a), although part of this increase is 
393 likely to be compensated by the increase of upward surface LW radiation due to 394 surface warming (Fig. 9b). The positive change of net clear sky LW radiation is partly 395 due to direct impact of incease in GHG concentrations and partly due to increases of 396 water vapor in the atmosphere related to GHG induced ocean warming (Fig. 9c). 397 Furthermore, the net surface SW radiation is increased over northern part of China (Fig. 398 9d), which is mainly due to the increase of net clear sky SW radiation (Fig. 9e). The 399 positive clear sky SW radation, with a vaule of $4.5 \mathrm{~W} \mathrm{~m}^{-2}$ over $\mathrm{NC}$, results from snow 400 albedo feedback through the reduction of snow cover and depth due to skin temperature 401 warming (Fig. 9f; e.g., Robock 1983; Yang et al. 2001; Bony et al. 2006; Qu and Hall 402 2007; Thackeray and Fletcher 2016). In summary, the positive change in net clear sky 403 LW radiation due to the Greenhouse Effect and associated water vapor feedback 404 contribute to the warming over SWC and SEC and leads to changes in cold extremes. 405 The increase of net surface SW radiation, mainly due to the increase of clear sky SW 406 radiation related to decrease in snow cover and depth, leads to large changes in day407 time extremes of TXn and ID than night-time extremes of TNn and FD over NC.

\subsection{Induced by AA forcing changes}

Figure 10 is the spatial distributions of the winter mean changes for the key

410 components of surface energy balance and related variables induced by changes in AA

411 emissions. During winter, AA are advected by mean flow to the Indian Ocean and 412 western North Pacific, instead of that the AA effects are more over emission area due 413 to relatively weak advections during summer. There is significant cooling over the 
414 Indian Ocean and western North Pacific (Fig. 10a) results from the increased AA

415 advected by prevailing winds from South and East Asia. This cooling corresponds to

416 the decrease of water vapor extending from western North Pacific to East Asia (Fig.

417 10b). The decrease of water vapor in the atmosphere results in decrease of cloud cover

418 over Eastern China (Fig. 10c), which induces positive SW CRE (Fig. 10d). The

419 positive SW CRE, with a magnitude of $4.01 \mathrm{~W} \mathrm{~m}^{-2}$ over $\mathrm{NC}$ and SEC, contributes to

420 the local surface warming (Fig. 10a) and decrease in cold extremes over NC and SEC.

421 In addition, the decrease of upward latent heat flux (Fig. 10e; $1.33 \mathrm{~W} \mathrm{~m}^{-2}$ ), as a

422 consequences of decrease in evaporation (Fig. 10f), also makes a contribution to the

423 surface warming and a contribution to increase in TXn and TNn and decrease in

424 frequencies of ID and FD over SEC.

\section{7. Conclusions}

We found significant decadal changes in both hot and cold extremes over China

427 since the mid-1990s by using Chinese observed station dataset. These changes are

428 characterized as the rise in TXx, TNx and the increase in frequencies of SU and TR

429 during summer, and the rise in TXn and TNn and the decrease in frequencies of ID and

430 FD during winter. In this study, we have performed a set of experiments using an

431 atmosphere-ocean-mixed-layer coupled model to assess the contributions of All forcing

432 changes, as an combined effects of GHG and AA forcing, to observed decadal changes

433 in temperature extremes over China across the mid-1990s, and quantify the relatively

434 roles of changes in GHG concentrations and AA emissions, respectively. The main 
conclusions are as follow.

Observations indicate that there was an abrupt change in temperature extremes over China since the mid-1990s. The changes of temperature extremes are analyzed by the comparison between the PD of 1994 2011 and the EP of 1964 1981. Spatially averaged over China, the hot extremes of TXx and TNx are increased by $0.58{ }^{\circ} \mathrm{C}$ and $0.76{ }^{\circ} \mathrm{C}$, respectively. The frequencies of SU and TR are increased by about $7 \sim 9$ days. The cold extremes of TXn and TNn are increased by $1.48^{\circ} \mathrm{C}$ and $1.82^{\circ} \mathrm{C}$, respectively. The frequencies of ID and FD are decreased by about one week. Furthermore, these abrupt decadal changes occur not only over China as a whole, but also over three subregions of NC, SEC and SWC, even though they exhibit various climate types.

The atmosphere-ocean-mixed-layer coupled model MetUM-GOML1 in response to changes in GHG concentrations and AA emissions together (All forcing) realistically reproduces the spatial patterns of the observed decadal changes in both hot and cold temperature extremes. Quantitatively, the model simulated changes in response to All forcing changes are comparable to the observed decadal changes. The results indicate a dominant role of anthropogenic changes in the observed decadal changes of temperature extremes over China across the mid-1990s.

Moreover, model responses to changes in GHG concentration and AA emissions show some different characteristics. GHG forcing changes lead to increase in hot extremes (TXx, TNx, SU and TR), and TNx and TNn and decrease in frequencies of ID and FD over China, while AA forcing changes lead to weak increases in hot extremes 
over NC and decrease over SEC during summer and induce changes in cold extremes

457 the same sign as those induced by GHG over NC and SEC during winter, but with weak 458 magnitude. The responses of cold extremes in response to changes in GHG forcing are 459 two to three times as large as those in response to changes in AA forcing, indicating a 460 dominant role of GHG forcing changes in the model simulated cold extreme changes 461 in response to All forcing changes. Relatively, the increase of extremes over NC in 462 responses to changes in GHG forcing explains up to $75 \%$ of the TNx, $90 \%$ of the TXn 463 and $60 \%$ of the TNn increase in response to changes in All forcing (assuming linearity).

464 These results indicate that the model simulated extreme temperature changes in 465 response to All forcing changes are predominantly induced by GHG forcing change, 466 but AA change also makes some weak contributions.

467 In response to the increase of GHG concentrations, the increase of hot extremes is 468 mainly due to the increased Greenhouse Effect with positive net surface clear sky LW 469 radiation. Additionally, the increase of net surface SW radiation, mainly resulted from 470 the positive SW CRE, associated with the decrease of cloud cover, has a positive 471 feedback with the surface warming and the increase in hot extremes. In terms of 472 changes in cold extremes in response to GHG forcing changes, the increase of net 473 surface clear sky LW radiation due to the increased greenhouse effect and associated 474 water vapor feedback tend to result in surface warming over southern part of China, 475 and therefore lead to increase in TXn and TNn and decrease in frequencies of ID and 476 FD. The changes of cold day-time extremes (TXn and ID) over NC are further enhanced 
477 by the increase of clear sky SW radiation related to the decrease of snow-albedo 478 feedback.

479 During summer, the response of hot extremes over China to changes in AA forcing 480 exhibits a dipole pattern with increases in north and decreases in south. Local increase 481 of AOD over East Asia leads to decrease of net clear sky SW radiation, which tends to 482 cool the surface. However, the positive SW CRE tends to warm the surface and leads 483 to increase in hot extremes over NC. The positive SW CRE is induced by the decrease 484 of cloud cover, which related to the decrease of soil moisture, as a consequence of 485 reduction in precipitation over NC, while decreases in hot extremes over South China 486 are the results of direct impacts of AA forcing changes through aerosol-radiation and 487 aerosol-cloud interactions due to increased AA emissions over East Asia. During winter, 488 AA are advected by mean flow to the Indian Ocean and western North Pacific, which 489 induces cooling over there. This cooling reduces water vapor and therefore reduces 490 cloud cover over East Asia, leading to positive SW CRE over NC and SEC and 491 therefore leading to increase in TXn and TNn and decrease in frequencies of ID and FD 492 over NC and SEC.

493 In this study, besides the cooling effect by the direct impacts of AA forcing changes 494 through aerosol-radiation and aerosol-cloud interactions, we find a surface warming 495 over NC during summer and over China during winter driven by AA forcing changes 496 through the AA induced atmosphere-cloud feedback. This aerosol-climate interaction 497 is consistent with Tian et al. (2018).. 
The model shows a strong warming over China in response to GHG forcing, and a cooling over SC and a weak warming over $\mathrm{NC}$ in response to AA forcing during

501 summer. In addition, previous studies have pointed out different roles of GHG and AA 502 in shaping the temperature trend over China by using CMIP5 models. The CMIP5 experiments result suggested that the GHG plays a dominant role in the warming trend over China (e.g., Song et al. 2014; Zhao et al. 2015), which is consistent with our model result. Zhao et al. (2015) showed that the AA forcing has a cooling effect, and they 506 further indicated that the individual effects of AA cannot be detected in the observed temperature changes with respect to the combined effects among all the other forcings, implying an uncertainty about the AA forcing impact in their study. In addition, Li et

509 al. (2015) further suggested that the indirect AA effect (including indirect, semidirect,

510 surface albedo effects, and so on) induce warming over NC, which also can seen by our 511 model result.

512 The results in this study indicate a remarkable role of anthropogenic changes,

513 especially the increased GHG concentrations, in the observed decadal changes of 514 temperature extremes over China since the mid-1990s. Given the fact that GHG 515 concentrations and local AA emissions will continue to rise in the next few decades, 516 observed recent decadal changes in temperature extremes over China are likely to 517 sustain, or even amplify in the near future. 
521 Grants 41675078, U1502233, 41320104007, by the Youth Innovation Promotion 522 Association of CAS (No. 2018102) and by the UK-China Research \& Innovation 523 Partnership Fund through the Met Office Climate Science for Service Partnership 524 (CSSP) China as part of the Newton Fund. BD is supported by the U.K. National Centre 525 for Atmospheric Science-Climate (NCAS-Climate) at the University of Reading. The 526 authors thank Editor Jian Lu and anonymous reviewers for their constructive comments 527 on the earlier version of the paper. 
Alexander LV et al (2006) Global observed changes in daily climate extremes of temperature and precipitation. J Geophys Res 111:D05109. doi: 10.1029/2005JD006290

Arribas A et al (2011) The GloSea4 ensemble prediction system for seasonal forecasting. Monthly Weather Review 139(6):1891-1910

Barsugli J, Battisti D S (1998) The basic effects of atmosphere-ocean thermal coupling on midlatitude variability. J Atmos Sci 55:477-493. doi:10.1175/1520-0469

Bellouin N, Rae J, Jones A, Johnson C, Haywood J, Boucher O (2011) Aerosol forcing in the climate model intercomparison project (CMIP5) simulations by HadGEM2-ES and the role of ammonium nitrate. J Geophys Res 116:D20206. doi: 10.1029/2011JD016074

Boé J, Terray L (2014) Land-sea contrast, soil-atmosphere and cloud-temperature interactions: interplays and roles in future summer European climate change. Clim Dyn 42:683-699

Bollasina MA, Ming Y, Ramaswamy V (2011) Anthropogenic aerosols and the weakening of the South Asian summer monsoon. Science 334(6055):502-505

Bony S et al (2006) How well do we understand and evaluate climate change feedback processes? J Clim 19(15):3445-3482. doi: 10.1175/jcli3819.1

Christidis N et al (2013) A new HadGEM3-A-based system for attribution of weather and climate-related extreme events. J Clim 26:2756-2783. doi:10.1175/JCLI-D- 
550 Cubasch U et al (2001) Projections of future climate change. Climate Change 2001: The Scientific Basis, J. T. Houghton et al., Eds., Cambridge University Press $525-582$

Donat MG, Alexander LV, Yang H, Durre I, Vose R, Caesar J (2013) Global land-based datasets for monitoring climatic extremes. Bull Am Meteorol Soc 94:997-1006. doi:10.1175/BAMS-D-12-00109.1

Dong BW, Sutton RT, Shaffrey L (2017a) Understanding the rapid summer warming and changes in temperature extremes since the mid-1990s over Western Europe. Clim Dyn 48:1537-1554. doi:10.1007/s00382-016-3158-8

Dong BW, Sutton RT, Shaffrey L, Klingaman NP (2017b) Attribution of forced decadal climate change in coupled and uncoupled ocean-atmosphere model experiments. J Clim doi:10.1175/JCLI-D-16-0578.1

Dong BW, Sutton RT, Chen W, Liu XD, Lu RY, Sun Y (2016) Abrupt summer warming and changes in temperature extremes over Northeast Asia since the mid-1990s: Drivers and physical processes. Adv Atmos Sci 33(9):1005-1023. doi: $10.1007 / \mathrm{s} 00376-016-5247-3$

Dong BW, Sutton RT, Highwood E, Wilcox L (2015) Preferred response of the East Asian summer monsoon to local and nonlocal anthropogenic sulphur dioxide emissions. Clim Dyn doi:10.1007/s00382-015-2671-5 

response to increasing greenhouse gases. Part I: Transient adjustment. J Clim 22:3079-3097

Dwyer JG, Biasutti M, Sobel AH (2012) Projected changes in the seasonal cycle of surface temperature. J Clim 25(18):6359-6374

574 Feichter J, Roeckner E, Lohmann U, Liepert B (2004) Nonlinear aspects of the climate response to greenhouse gas and aerosol forcing. J Clim 17:23842398

Freychet S, Tett S, Wang J, Hegerl G (2017) Summer heat waves over eastern china: 10.1088/1748-9326/aa5ba3

Hansen J, Sato M, Ruedy R (1997) Radiative forcing and climate response. J Geophys Res 102:6831-6864. doi:10.1029/96JD03436

He J, Soden B (2016) Does the lack of coupling in SST-forced atmosphere-only models limit their usefulness for climate change studies? J Clim 29:4317-4325.

585 Hirons LC, Klingaman NP, Woolnough SJ (2015) MetUM-GOML: a near-globally 586 coupled atmosphere-ocean-mixed-layer model. Geoscientific Model

588 Jones $\mathrm{C}$ et al (2011) The HadGEM2-ES implementation of CMIP5 centennial simulations. Geophys Model Dev 4:543-570

590 Kamae Y, Shiogama H, Watanabe M, Kimoto M (2014) Attributing the increase in 
Kim YH, Min SK, Zhang X, Zwiers F, Alexander LV, Donat MG, Tung YS (2015) Attribution of extreme temperature changes during 1951-2010. Clim Dyn 46:1769-1782. doi:10.1007/ s00382-015-2674-2 burning emissions of reactive gases and aerosols: Methodology and application. Atmos Chem Phys 10:7017-7039. doi:10.5194/acp-10-7017-2010

Lamarque JF et al (2011) Global and regional evolution of short-lived radiatively-active

600

601 gases and aerosols in the Representative Concentration Pathways. Climatic Change 109:191-212. doi:10.1007/s10584-011-0155-0

602 Li CX, Zhao TB, Ying KR (2015) Effects of anthropogenic aerosols on temperature 603 changes in China during the twentieth century based on CMIP5 models. Theor 604 Appl Climatol doi: 10.1007/s00704-015-1527-6

Li X, Ting M (2016) Understanding the Asian summer monsoon response to 606 607 greenhouse warming: the relative roles of direct radiative forcing and sea surface

$608 \mathrm{Li} \mathrm{Z}$ et al (2016) Comparison of two homogenized datasets of daily 609 maximum/mean/minimum temperature in China during 1960-2013. J Meteor Res 30(1):053-066. doi: 10.1007/s13351-016-5054-x

611 Ma SM, Zhou TJ, Stone D, Angelil O, Shiogama H (2017) Attribution of the July- 

August 2013 heat event in central and eastern China to anthropogenic Greenhouse gas emissions. Environ Res Lett 12:054020

614 Ming Y, Ramaswamy V (2009) Nonlinear climate and hydrological responses to aerosol effects. J Clim 22:1329-1339

Otto FE, Massey, van Oldenborgh GJ, Jones RQ, Allen MR (2012) Reconciling two approaches to attribution of the 2010 Russian heat wave. Geophys Res Lett 39:L04702. doi:10.1029/2011GL050422

Perkins SE (2015) A review on the scientific understanding of heatwaves--their measurement, driving mechanisms, and changes at the global scale. Atmos Res $164: 242-267$

Qu X, Hall A (2007) What controls the strength of snow-albedo feedback? J Clim

Randall DA et al (1994) Analysis of snow feedbacks in 14 general circulation models. 20(15):3971-3981, doi: doi:10.1175/JCLI4186.1 J Geophys Res Atmos 99(D10):20757-20771. doi: 10.1029/94jd01633

Rangwala I, Sinsky E, Miller JR (2016) Variability in projected elevation dependent warming in boreal midlatitude winter in CMIP5 climate models and its potential drivers. Clim Dyn 46:2115

Rayner NA et al (2003) Global analyses of sea surface temperature, sea ice, and night marine air temperature since the late nineteenth century. J Geophys Res 108:4407. 
634 Schaller N et al (2016) Human influence on climate in the 2014 southern England winter floods and their impacts. Nat Clim Change 6:627-634. doi:10.1038/nclimate2927

Shiogama H, Stone DA, Nagashima T, Nozawa T, Emori S (2012) On the linear additivity of climate forcing-response relationships at global and continental scales. Int J Climatol 33:2542-50

Smith DM, Murphy JM (2007) An objective ocean temperature and salinity analysis using covariances from a global climate model. J Geophys Res 112:C02022. doi:10.1029/2005JC003172

Song F, Zhou T, Qian Y (2014) Responses of East Asian summer monsoon to natural and anthropogenic forcings in the 17 latest CMIP5 models. Geophys Res Lett 41. a buffered system. Nat 461:607-613. doi:10.1038/nature08281

648 Stouffer RJ, Wetherald RT (2007) Changes of variability in response to increasing greenhouse gases. part i: temperature. J Clim 20(21):5455

650 Stott et al (2016) Attribution of extreme weather and climate-related events. Wiley Interdiscip. Rev Clim Change 7:23-41. doi:10.1002/wcc.380

652 Sun Y, Song LC, Yin H, Zhang XB. Stott P, Zhou BT, Hu T (2016) Human Influence 653 on the 2015 extreme high temperature events in western China [in "Explaining 

97:S5-S9.

Sun Y, Zhang X, Zwiers FW, Song L, Wan H, Hu T, Yin H, Ren G (2014) Rapid increase in the risk of extreme summer heat in Eastern China. Nat Clim Change 4:10821085. doi:10.1038/nclimate 2410

Tian FX, Dong BW, Robson J Sutton RT (2018) Forced decadal changes in the East Asian summer monsoon: the roles of greenhouse gases and anthropogenic aerosols. Clim Dyn 6:1-17

Thackeray CW, Fletcher CG (2016) Snow albedo feedback: Current knowledge, importance, outstanding issues and future directions. Prog Phys Geogr 40(3):392-408. doi: 10.1177/0309133315620999

Vannière BE, Guilyardi G, Madec FJ, Doblas R, Woolnough S (2013) Using seasonal hindcasts to understand the origin of the equatorial cold tongue bias in CGCMs and its impact on ENSO. Clim Dyn 40(3-4):963-981

Walters DN, Best MJ, Bushell AC, Copsey D, Edwards JM, Falloon PD, Roberts MJ (2011) The met office unified model global atmosphere 3.0/3.1 and JULES global land 3.0/3.1 configurations. Geosci Model Dev 4(4):919

Wang $\mathrm{T}$ et al (2013) Anthropogenic agent implicated as a prime driver of shift in precipitation in eastern China in the late 1970s. Atmos Chem Phy 13(24):12433

Wang T, Otterå OH, Gao YG, Wang HJ (2012) The response of the North Pacific Decadal Variability to strong tropical volcanic eruptions. Clim Dyn 39(12):2917- 
676 Wei K, Chen W (2011) An abrupt increase in the summer high temperature extreme days across China in the mid-1990s. Adv Atmos Sci 28(5):1023-1029. doi: $10.1007 / \mathrm{s} 00376-010-0080-6$

Wen HQ, Zhang X, Xu Y, Wang B (2013) Detecting human influence on extreme 680 temperatures in China. Geophys Res Lett 40:1171-1176. doi:10.1002/grl.50285.

681 Wilcox LJ, Dong BW, Sutton RT, Highwood EJ (2015) The 2014 Hot, Dry Summer in 682 Northeast Asia [in "Explaining Extreme Events of 2014 from a Climate 683 Perspective"]. Bull Amer Meteor Soc 96(12):S105-S110. doi:10.1175/BAMS-

684 D-15-00123.1

Yang FL et al (2001) Snow-albedo feedback and seasonal climate variability over North 686 America. J Clim 14(22):4245-4248 sea salt emissions enhance ENSO variability, J Clim 29:8575-8588. doi:10.1175/JCLI-D-16-0237.1

690 Yang Y, Russell LM, Lou S, Liao H, Guo J, Liu Y, Singh B, Ghan SJ (2017) Dust-wind 691 692 interactions can intensify aerosol pollution over eastern China. Nat Commun 8:15333. doi:10.1038/ncomms 15333

693 Yao Y, Luo Y, Huang JB (2012) Evaluation and projection of temperature extremes over 694 China based on CMIP5 model. Adv Clim Change Res 3(4). doi: 695 10.3724/SP.J.1248.2012.00179 
696 Yin H, Sun Y, Wan H, Zhang XB, Lu CH (2016) Detection of anthropogenic influence 697 on the intensity of extreme temperatures in China. Int J Climatol 37:1229-1237. 698 doi: $10.1002 /$ joc. 4771

699 Zhao TB, Li CX, Zuo ZY (2016) Contributions of anthropogenic and external natural 700 forcings to climate changes over China based on CMIP5 model simulations. Sci 701 China Earth Sci 59:503-517. doi: 10.1007/s11430-015-5207-2

702 Zhou BT, Xu Y, Wu J, Dong S, Shi Y (2016) Changes in temperature and precipitation 703 extreme indices over China: analysis of a high-resolution grid dataset. Int $\mathrm{J}$ $704 \quad$ Climatol 36:1051-1066 


\section{Figure captions}

706 Table 1. Summary of numerical experiments.

707 Figure 1. Time series of annual mean temperature extremes anomalies relative to the climatology (mean of the whole period) in summer (TXx, TNx, SU and TR; left panels) and in winter (TXn, TNn, ID and FD; right panels) over China by GHCND dataset (averaged over $20^{\circ} \sim 55^{\circ} \mathrm{N}, 7^{\circ} \sim 130^{\circ} \mathrm{E}$; black solid lines) and by China station dataset (averaged over 753 stations; red solid lines). The color dashed lines

Figure 2. (a) Distributions of 753 stations in China station dataset. The three sub-

Figure 3. Differences in annual mean sulfur dioxide emissions (units: $\mathrm{g} \mathrm{m}^{-2} \mathrm{yr}^{-1}$ ) between 1994 2010 and 1970 1981.

Figure 4. Spatial patterns of changes in hot extremes in response to changes in All forcing (left panels), GHG forcing (middle panels) and AA forcing (right panels), being masked by China boundary. The black lines indicate the regions where the changes are statistically significant at the $90 \%$ confidence level base on $t$-test. Units in TXx and TNx are ${ }^{\circ} \mathrm{C}$. Units in SU and TR are days. 
Figure 5. Same as Fig. 4, but for changes in cold extremes. Units in TNx and TNn are ${ }^{\circ} \mathrm{C}$. Units in ID and FD are days.

Figure 6. Observed and model simulated changes in temperature extremes in response to different forcings over Northern China ( $\mathrm{a}, \mathrm{b} ; \mathrm{NC}, 35^{\circ} \sim 55^{\circ} \mathrm{N}, 75^{\circ} \sim 130^{\circ} \mathrm{E}$ ), Southeastern China (c, d; SEC; $\left.20^{\circ} \sim 35^{\circ} \mathrm{N}, 105^{\circ} \sim 130^{\circ} \mathrm{E}\right)$ and Southwestern China (e, f; SWC; $20^{\circ} \sim 35^{\circ} \mathrm{N}, 75^{\circ} \sim 105^{\circ} \mathrm{E}$ ). The model simulated values have been masked by China boundary. The color bars indicate central estimates and dots show the $90 \%$ confidence intervals based on two-tailed Students't-test. Top panels for TXx, TXn, TNx and TNn (units: ${ }^{\circ} \mathrm{C}$ ) and bottom panels for SU, TR, ID and FD (units: days).

Figure 7. Spatial patterns of summer mean response to changes in GHG forcing: (a) clear sky LW radiation; (b) surface LW radiation; (c) total cloud cover (units: \%) (d) low level cloud cover (units: \%); (e) SW CRE; and (f) surface SW radiation. Radiation is the net component and in $\mathrm{W} \mathrm{m}^{-2}$ with positive value meaning downward. The black lines highlight regions where the changes are statistically significant at the $90 \%$ confidence level base on $t$-test.

Figure 8. Spatial patterns of summer mean response to changes in AA forcing: (a) total AOD; (b) clear sky SW radiation; (c) SW CRE; (d) total cloud cover (units: \%); (e) soil moisture (units: $\mathrm{kg} \mathrm{m}^{-2}$ ); and (f) column-integrated water vapor (units: $\mathrm{kg} \mathrm{m}^{-2}$ ). Radiation is the net component and in $\mathrm{W} \mathrm{m}^{-2}$ with positive value meaning downward. The black lines highlight regions where the changes are statistically significant at the $90 \%$ confidence level base on $t$-test.

Figure 9. Spatial patterns of winter mean response to changes in GHG forcing: (a) clear sky LW radiation; (b) surface LW radiation; (c) column-integrated water vapor (units: $\mathrm{kg} \mathrm{m}^{-2}$ ); (d) surface $\mathrm{SW}$ radiation; (e) clear sky SW radiation; and (f) skin temperature (units: ${ }^{\circ} \mathrm{C}$ ). Radiation is the net component and in $\mathrm{W} \mathrm{m}^{-2}$ with positive value meaning downward. The black lines highlight regions where the changes are statistically significant at the $90 \%$ confidence level base on $t$-test.

Figure 10. Spatial patterns of winter mean response to changes in AA forcing: (a) skin 
temperature (units: ${ }^{\circ} \mathrm{C}$ ); (b) column-integrated water vapor (units: $\mathrm{kg} \mathrm{m}^{-2}$ ); (c) total cloud cover (units: \%); (d) SW CRE; (e) surface latent hear flux; and (f) evaporation (units: $\mathrm{kg} \mathrm{m}^{-2}$ ). Radiation and flux are in $\mathrm{W} \mathrm{m}^{-2}$ with positive value meaning downward. The black lines highlight regions where the changes are

764 statistically significant at the $90 \%$ confidence level base on $t$-test. 
Table 1. Summary of numerical experiments. Note that a slightly different period of 1970-1981 for the aerosol forcing in the early period is used since aerosol emissions data before 1970 were not available

\begin{tabular}{|c|c|c|c|}
\hline Adv. & Experiment & Ocean & Radiative Forcing \\
\hline R0 & Relaxation run & $\begin{array}{l}\text { Relaxation to "present } \\
\text { day" (PD, 1994-2011) } \\
\text { mean 3D ocean } \\
\text { temperature and } \\
\text { salinity to diagnose } \\
\text { climatological } \\
\text { temperature and } \\
\text { salinity tendencies }\end{array}$ & $\begin{array}{l}\text { PD greenhouse gases (GHGs) } \\
\text { over 1994 2011 and } \\
\text { anthropogenic aerosol (AA) } \\
\text { emissions over 1994 2010 } \\
\text { with AA after } 2006 \text { from } \\
\text { RCP4.5 scenario (Lamarque et } \\
\text { al. 2010, 2011) }\end{array}$ \\
\hline EP & $\begin{array}{l}\text { Early period (EP } \\
\text { 1964 1981) }\end{array}$ & $\begin{array}{l}\text { Climatological } \\
\text { temperature and } \\
\text { salinity tendencies } \\
\text { from relaxation run }\end{array}$ & $\begin{array}{l}\text { EP GHGs over } 1964 \sim 1981 \\
\text { and AA emissions over } \\
1970 \sim 1981\end{array}$ \\
\hline PDGA & $\begin{array}{l}\text { Present Day (PD } \\
\text { 1994 2011) } \\
\text { with GHG and } \\
\text { AA forcings }\end{array}$ & \multirow{3}{*}{$\begin{array}{l}\text { Climatological } \\
\text { temperature and } \\
\text { salinity tendencies } \\
\text { from relaxation run }\end{array}$} & $\begin{array}{l}\text { PD GHG and PD AA } \\
\text { emissions }\end{array}$ \\
\hline PDG & $\begin{array}{l}\text { Present Day (PD } \\
\text { 1994 2011) } \\
\text { with GHG } \\
\text { forcing }\end{array}$ & & $\begin{array}{l}\text { PD GHG and EP AA } \\
\text { emissions }\end{array}$ \\
\hline PDA & $\begin{array}{l}\text { Present Day (PD } \\
\text { 1994 2011) } \\
\text { with AA forcing }\end{array}$ & & $\begin{array}{l}\text { EP GHG and PD AA } \\
\text { emissions }\end{array}$ \\
\hline
\end{tabular}



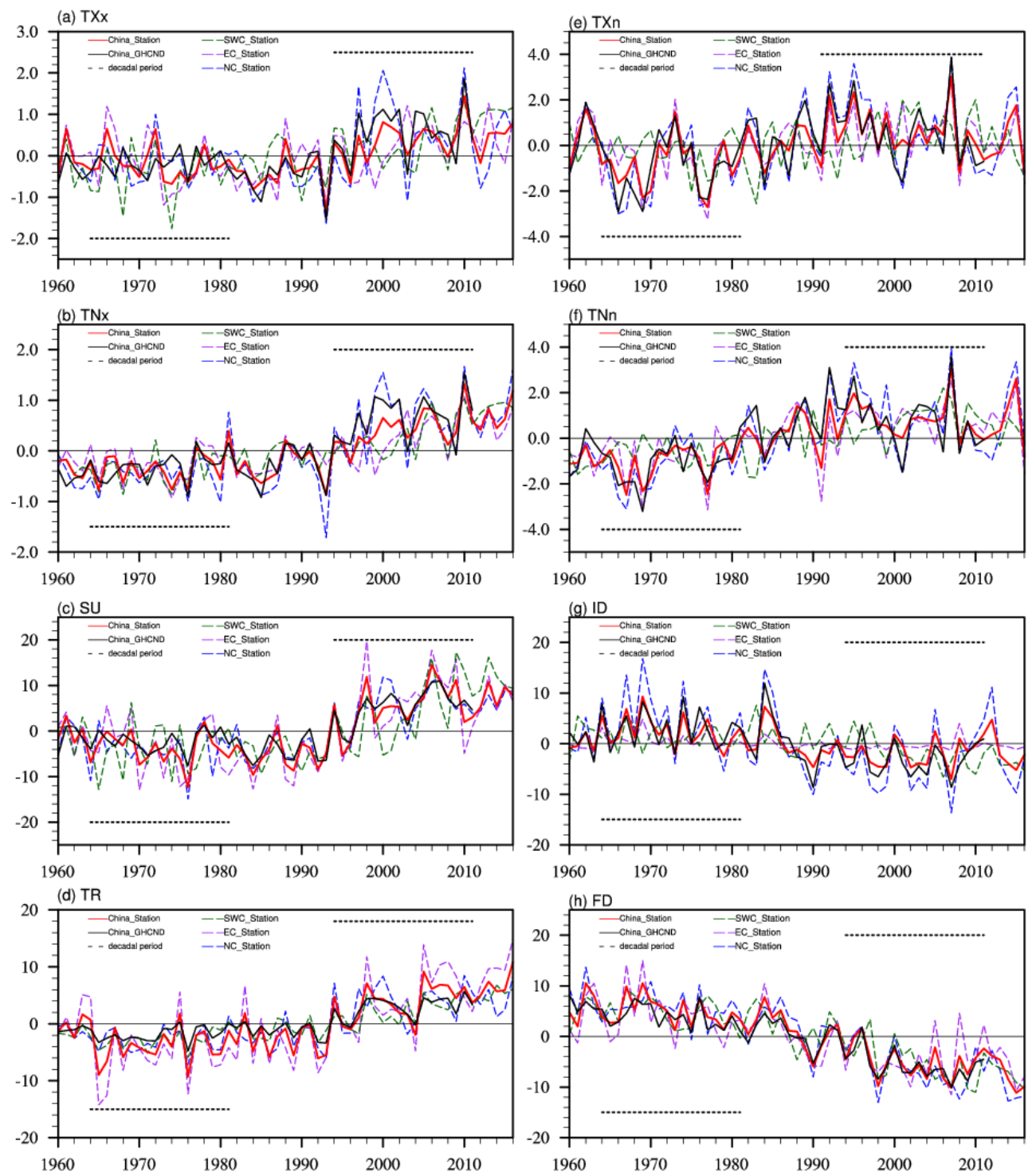

Figure 1. Time series of annual mean temperature extremes anomalies relative to the climatology (mean of the whole period) in summer (TXx, TNx, SU and TR; left panels) and in winter (TXn, TNn, ID and FD; right panels) over China by GHCND dataset (averaged over $20^{\circ} \sim 55^{\circ} \mathrm{N}$, $75^{\circ} \sim 130^{\circ} \mathrm{E}$; black solid lines) and by China station dataset (averaged over 753 stations; red solid lines). The color dashed lines represent the time series of temperature extremes anomalies averaged over three sub-regions by China station dataset (see their distributions in Fig. 2a). Black dashed range bars indicate the early period (EP) of 1964 1981 and the present day (PD) of 1994 2011. Units in TXx, TNx, TXn, and TNn are ${ }^{\circ} \mathrm{C}$. Units in SU, TR, ID and FD are days. 

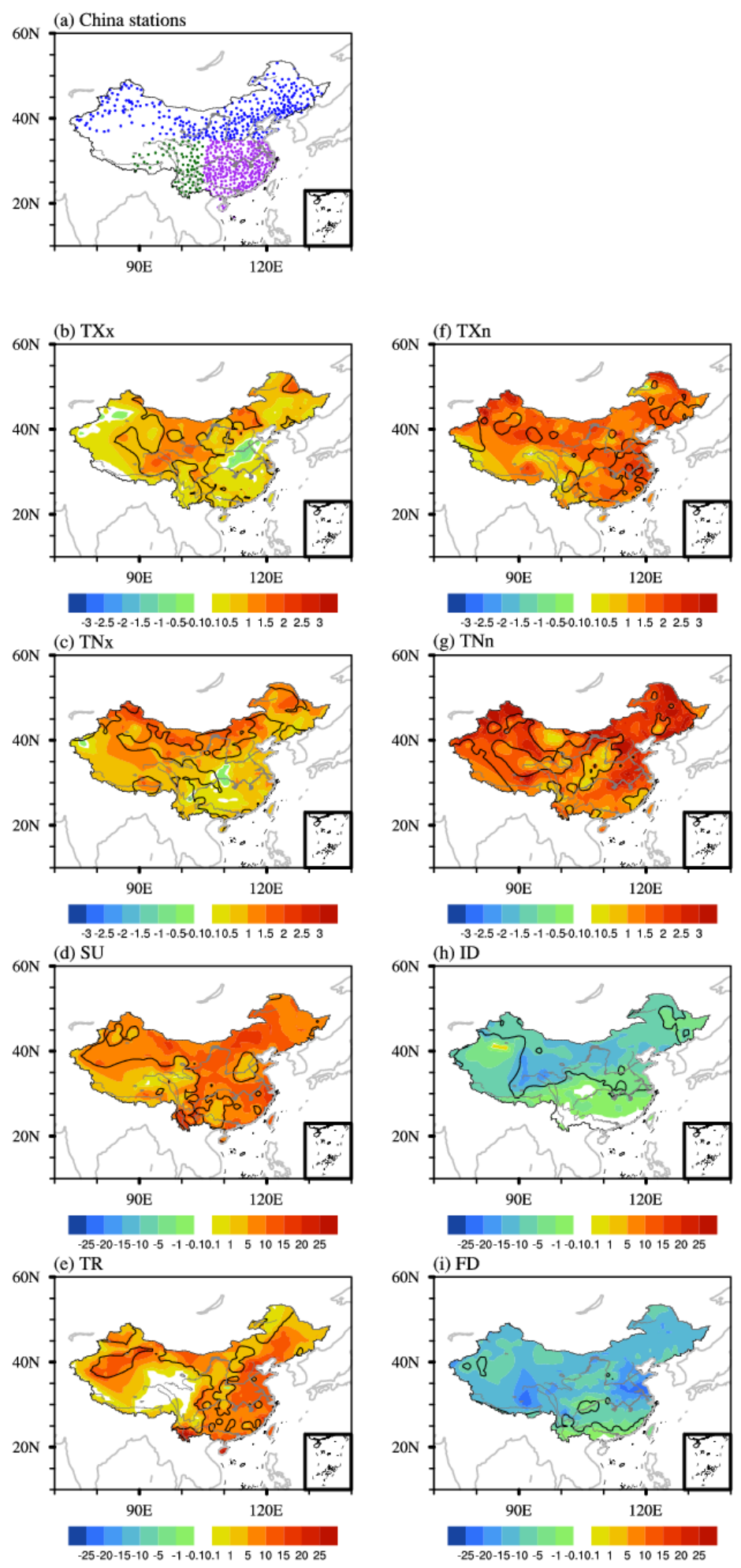

Figure 2. (a) Distributions of 753 stations in China station dataset. The three sub-regional groups are marked with different color dots. The dots in blue, purple and green represent the subregions of Northern China (NC), Southeastern China (SEC) and Southwestern China (SWC), respectively. (b)-(i) Spatial patterns of differences in temperature extremes in summer (left panels) and in winter (right panels) between the PD and the EP. The black lines indicate the regions where the changes are statistically significant at the $90 \%$ confidence level base on $t$ test. Units in TXx, TNx, TXn and TNn are ${ }^{\circ} \mathrm{C}$. Units in SU, TR, ID and FD are days. 


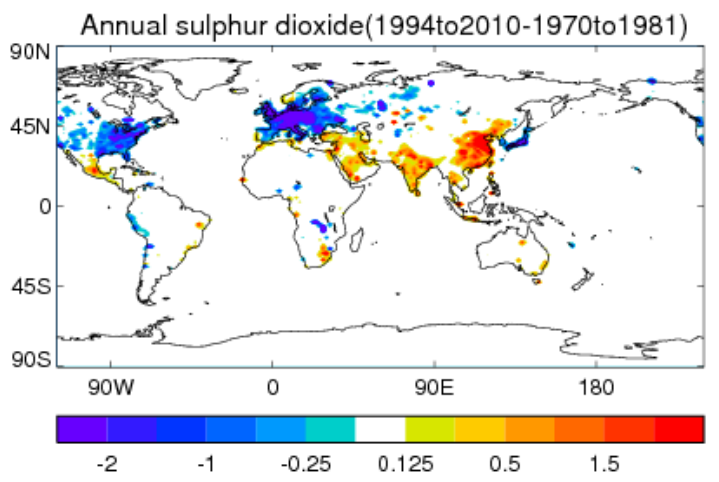

Figure 3. Differences in annual mean sulfur dioxide emissions (units: $\mathrm{g} \mathrm{m}^{-2} \mathrm{yr}^{-1}$ ) between 1994 2010 and 1970 1981. 

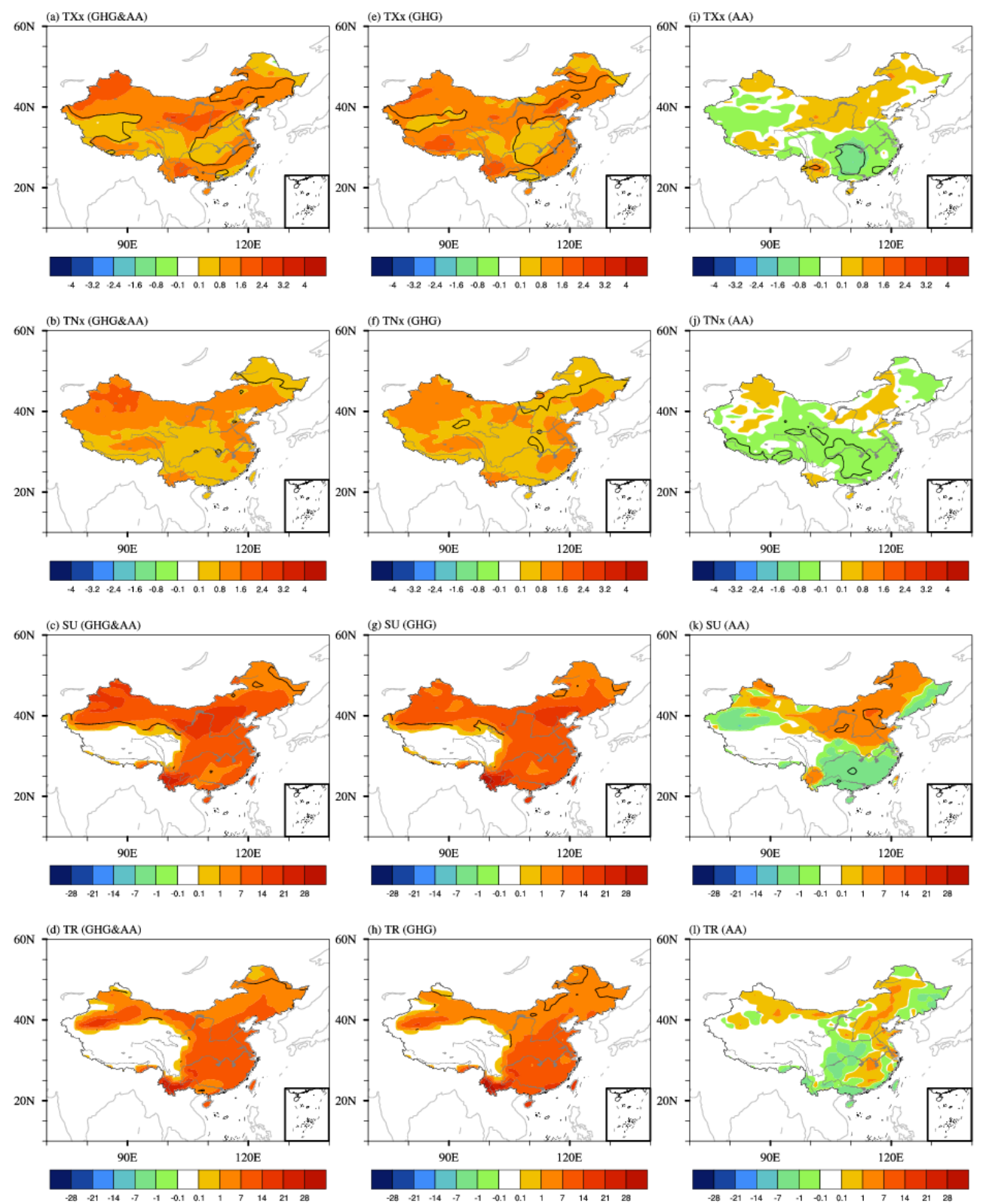

Figure 4. Spatial patterns of changes in hot extremes in response to changes in All forcing (left panels), GHG forcing (middle panels) and AA forcing (right panels), being masked by China boundary. The black lines indicate the regions where the changes are statistically significant at the $90 \%$ confidence level base on $t$-test. Units in TXx and TNx are ${ }^{\circ} \mathrm{C}$. Units in SU and TR are days. 

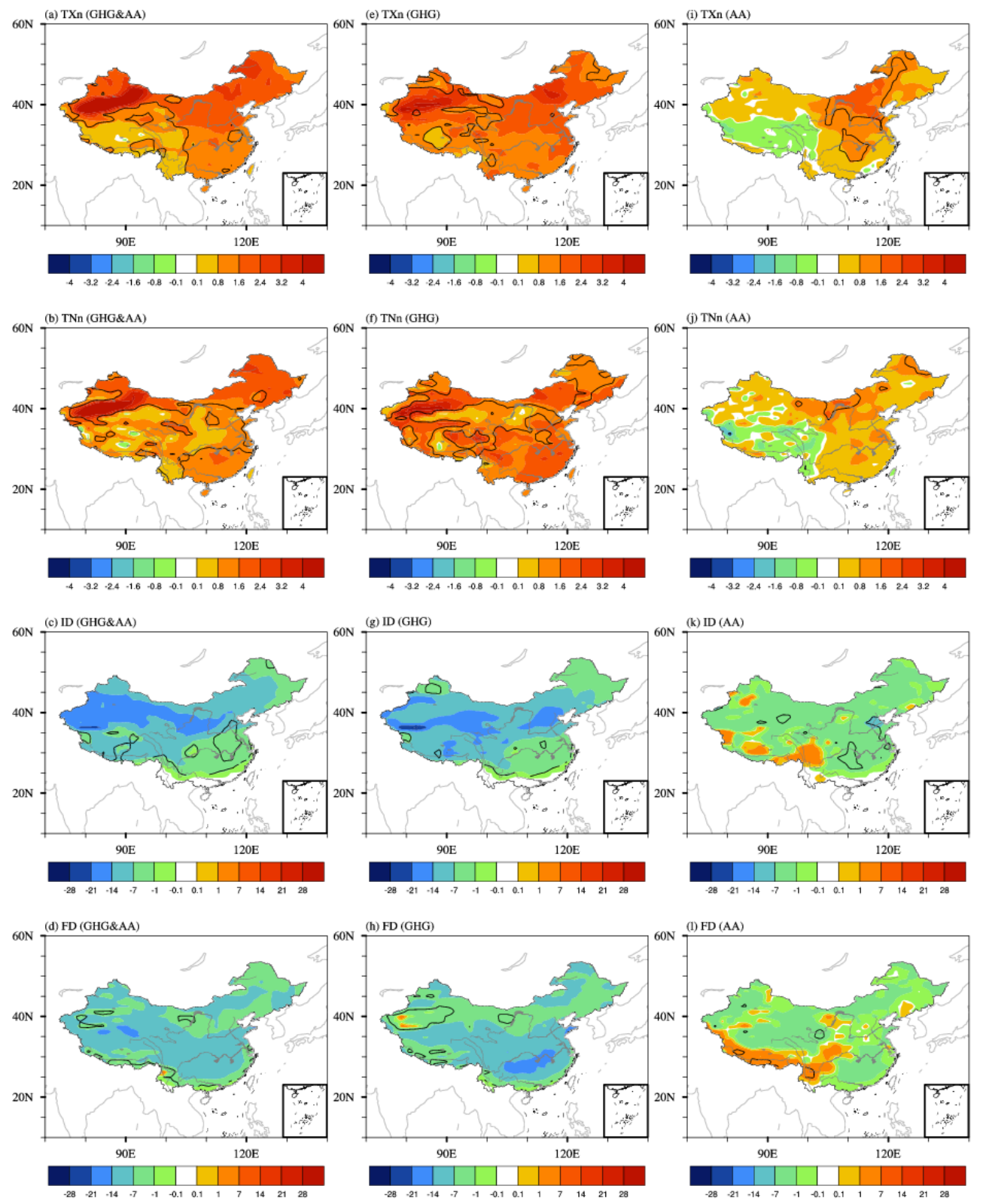

Figure 5. Same as Fig. 4, but for changes in cold extremes. Units in TNx and TNn are ${ }^{\circ} \mathrm{C}$. Units in ID and FD are days. 

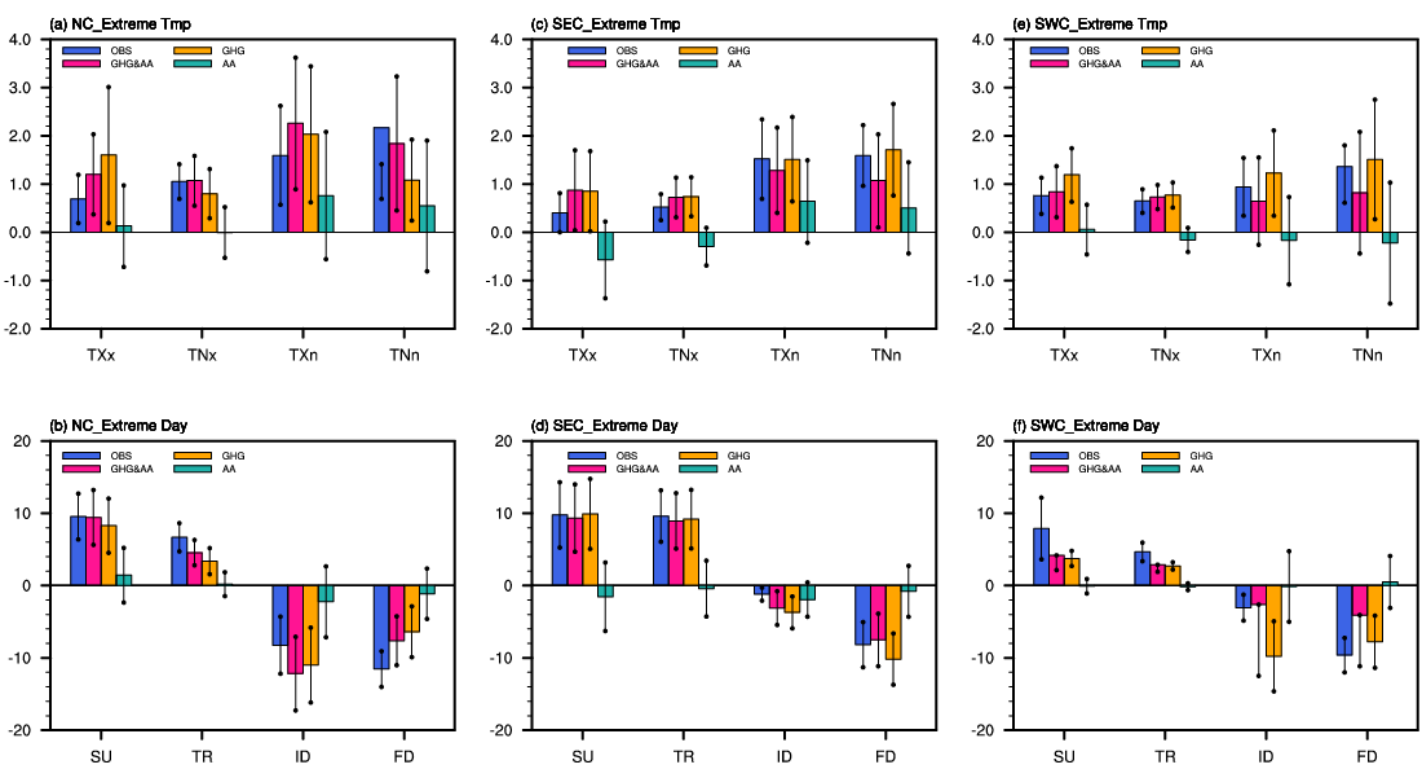

Figure 6. Observed and model simulated changes in temperature extremes in response to different forcings over Northern China (a, b; NC, 35 $\sim 55^{\circ} \mathrm{N}, 75^{\circ} \sim 130^{\circ} \mathrm{E}$ ), Southeastern China (c, d; SEC; $20^{\circ} \sim 35^{\circ} \mathrm{N}, 105^{\circ} \sim 130^{\circ} \mathrm{E}$ ) and Southwestern China (e, f; SWC; $20^{\circ} \sim 35^{\circ} \mathrm{N}, 75^{\circ} \sim 105^{\circ} \mathrm{E}$ ). The model simulated values have been masked by China boundary. The color bars indicate central estimates and dots show the $90 \%$ confidence intervals based on two-tailed Students' $t$-test. Top panels for TXx, TXn, TNx and TNn (units: ${ }^{\circ} \mathrm{C}$ ) and bottom panels for SU, TR, ID and FD (units: days). 
(a) JJA_clear sky LW (GHG)

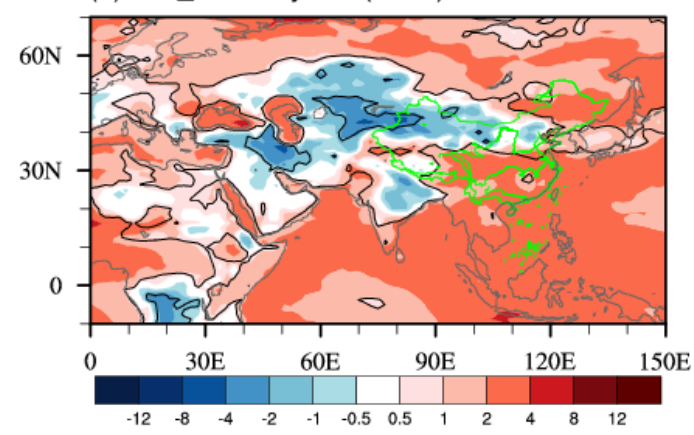

(c) JJA_Total Cloud (GHG)

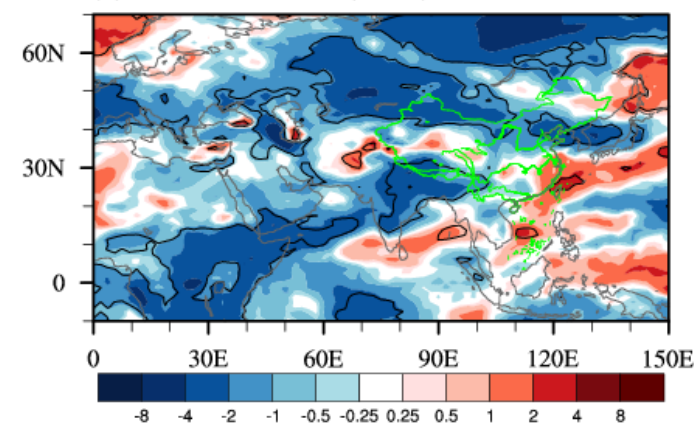

(e) JJA_SW CRE (GHG)

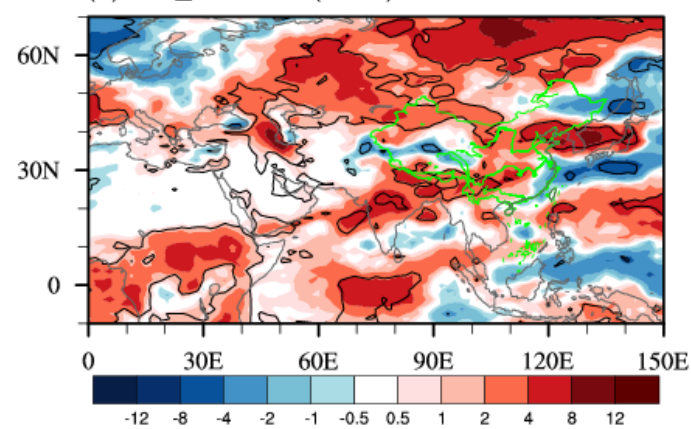

(b) JJA_LW (GHG)

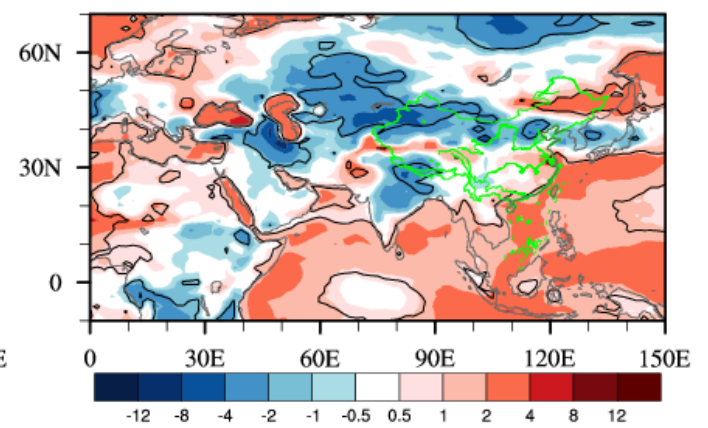

(d) JJA_Low Cloud (GHG)

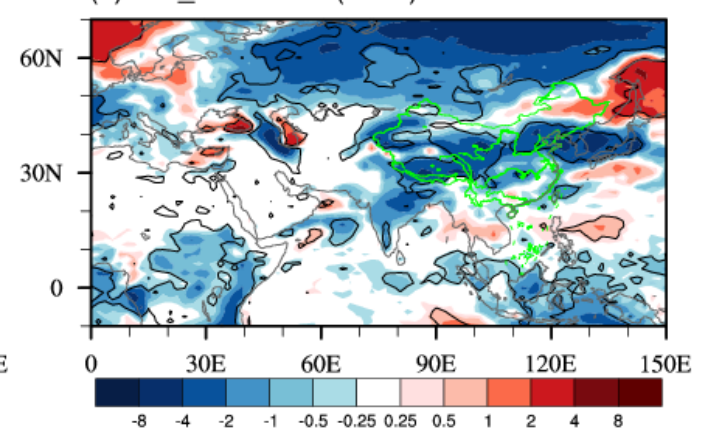

(f) JJA_SW (GHG)

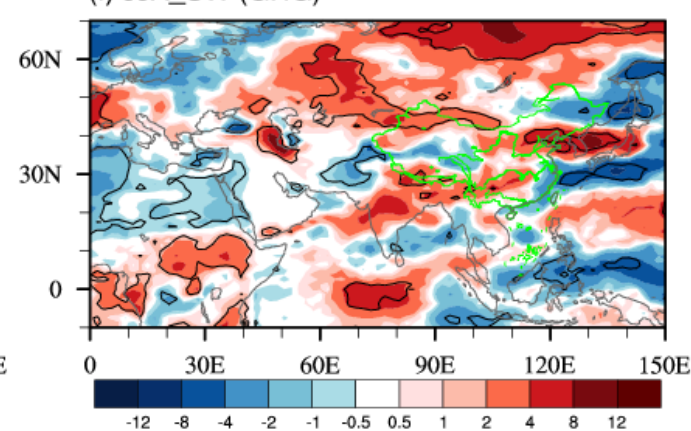

Figure 7. Spatial patterns of summer mean response to changes in GHG forcing: (a) clear sky LW radiation; (b) surface LW radiation; (c) total cloud cover (units: \%) (d) low level cloud cover (units: \%); (e) SW CRE; and (f) surface SW radiation. Radiation is the net component and in $\mathrm{W} \mathrm{m}^{-2}$ with positive value meaning downward. The black lines highlight regions where the changes are statistically significant at the $90 \%$ confidence level base on $t$-test. 
(a) JJA AOD (AA)

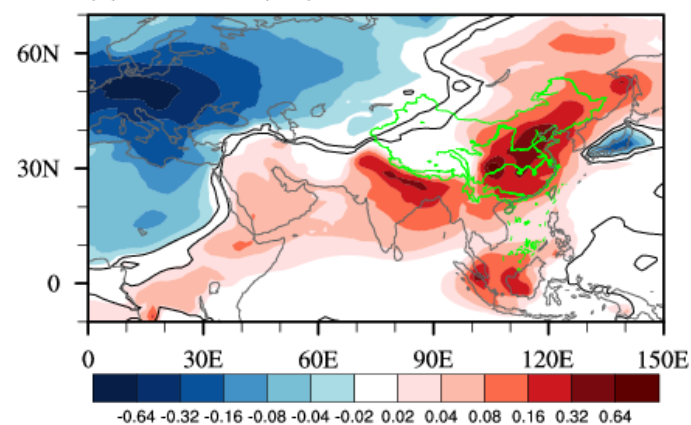

(c) JJA_SW CRE(AA)

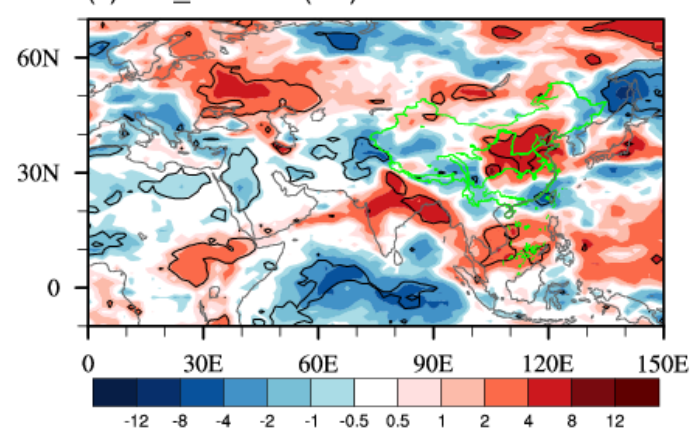

(e) JJA_Soil moisture (AA)

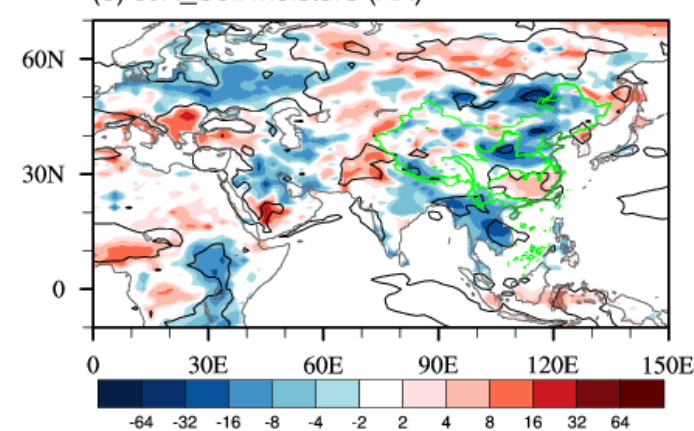

(b) JJA_clear sky SW (AA)

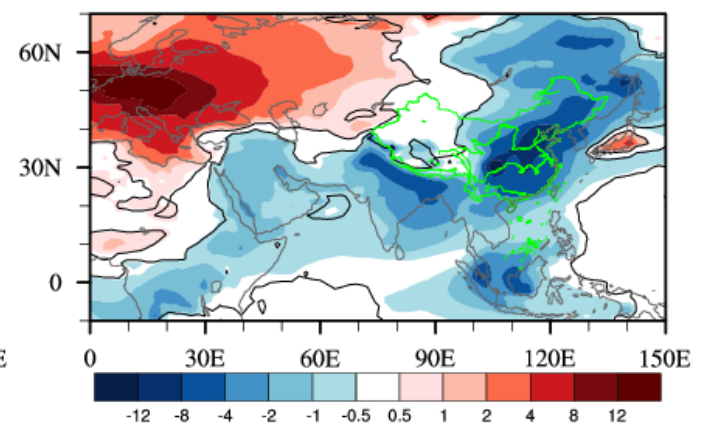

(d) JJA_Total Cloud (AA)

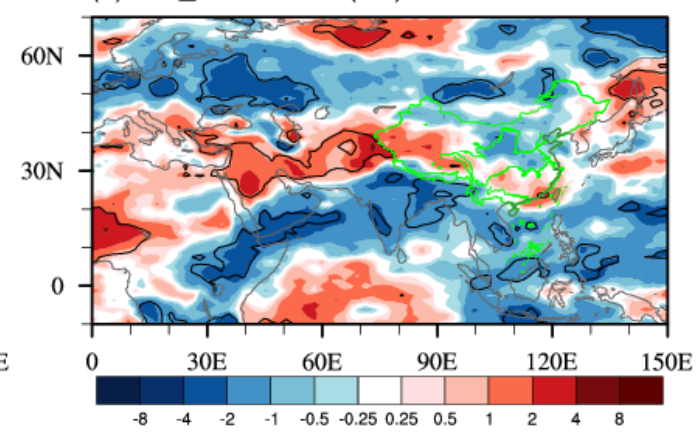

(f) JJA_Water vapor (AA)

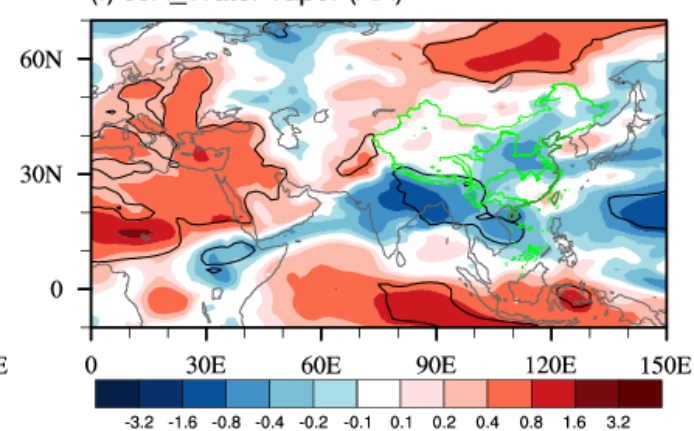

Figure 8. Spatial patterns of summer mean response to changes in AA forcing: (a) total AOD at 0.55 um; (b) clear sky SW radiation; (c) SW CRE; (d) total cloud cover (units: \%); (e) soil moisture (units: $\mathrm{kg} \mathrm{m}^{-2}$ ); and (f) column-integrated water vapor (units: $\mathrm{kg} \mathrm{m}^{-2}$ ). Radiation is the net component and in $\mathrm{W} \mathrm{m}^{-2}$ with positive value meaning downward. The black lines highlight regions where the changes are statistically significant at the $90 \%$ confidence level base on $t$ test. 
(a) DJF_clear sky LW (GHG)

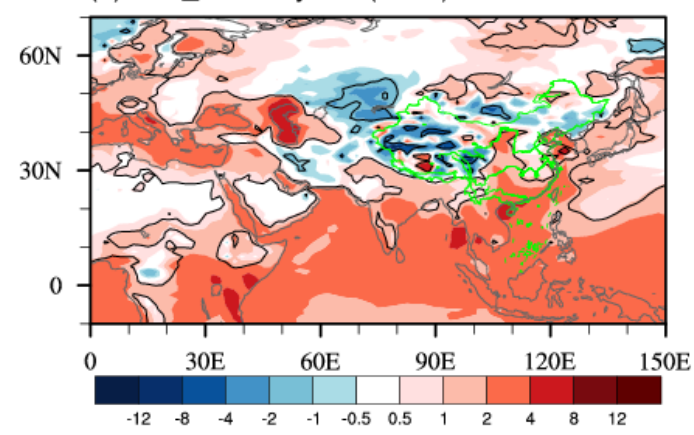

(c) DJF_Water vapor (GHG)

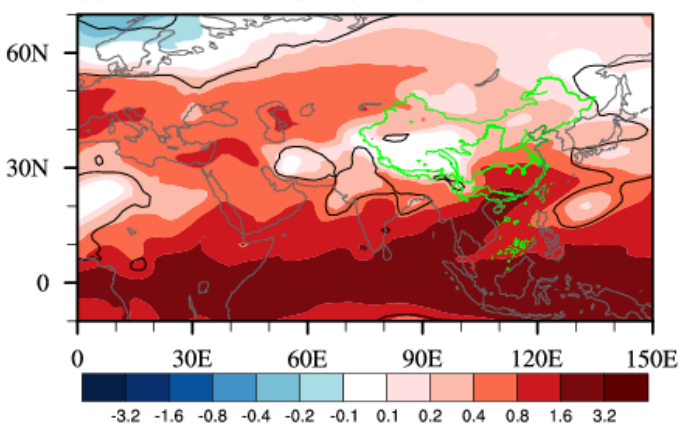

(e) DJF_clear sky SW (GHG)

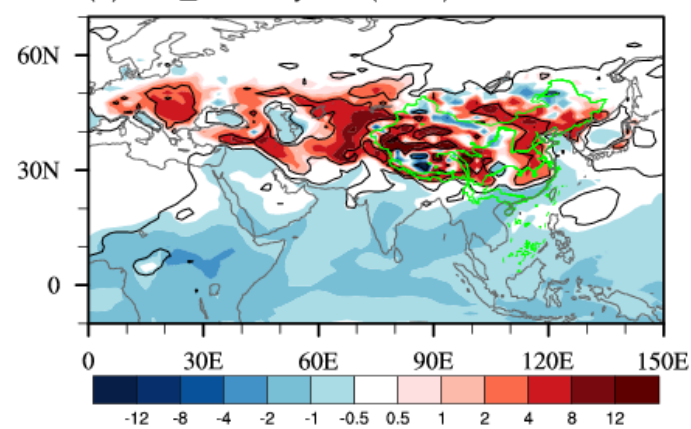

(b) DJF LW (GHG)

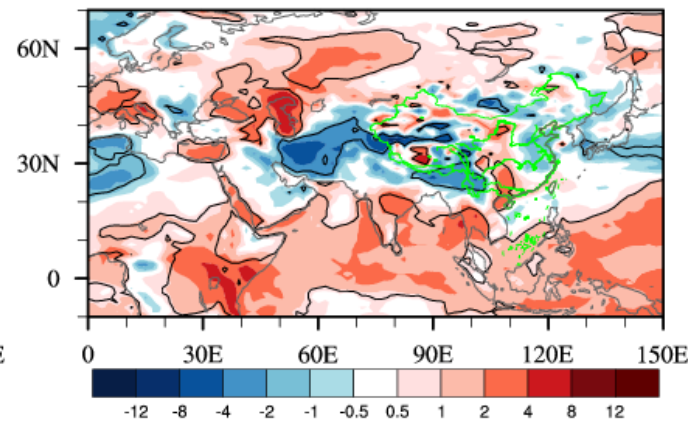

(d) DJF_SW (GHG)

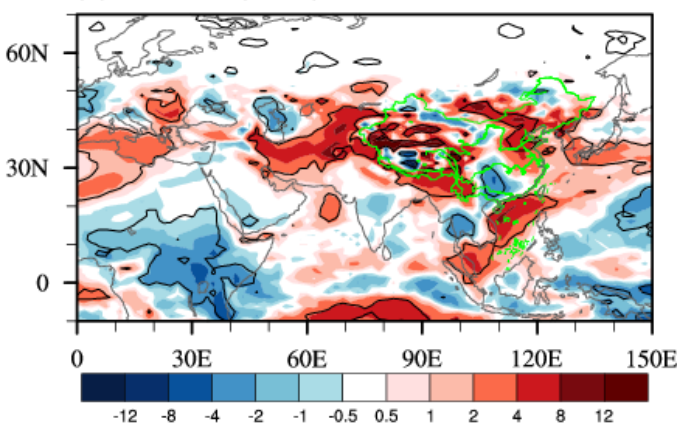

(f) DJF_Ts (GHG)

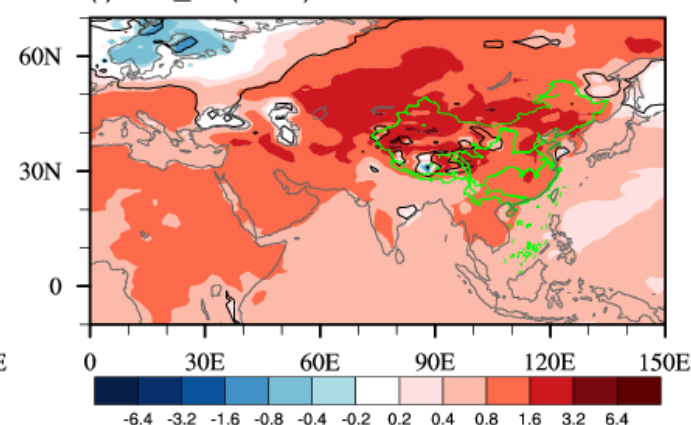

Figure 9. Spatial patterns of winter mean response to changes in GHG forcing: (a) clear sky LW radiation; (b) surface LW radiation; (c) column-integrated water vapor (units: $\mathrm{kg} \mathrm{m}^{-2}$ ); (d) surface SW radiation; (e) clear sky SW radiation; and (f) skin temperature (units: ${ }^{\circ} \mathrm{C}$ ). Radiation is the net component and in $\mathrm{W} \mathrm{m}^{-2}$ with positive value meaning downward. The black lines highlight regions where the changes are statistically significant at the $90 \%$ confidence level base on $t$-test. 
(a) DJF_Ts (AA)

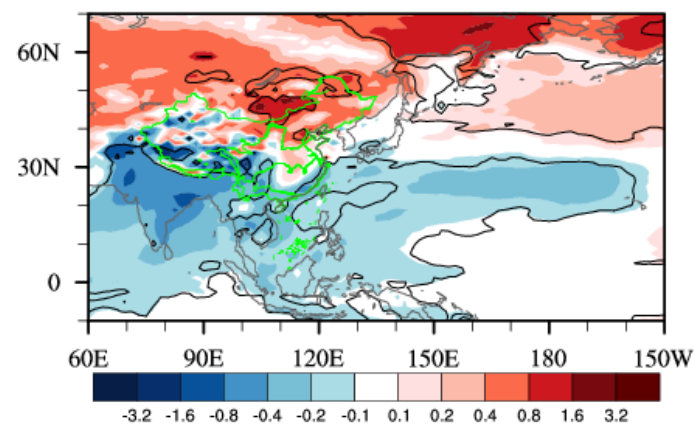

(c) DJF_Total Cloud (AA)

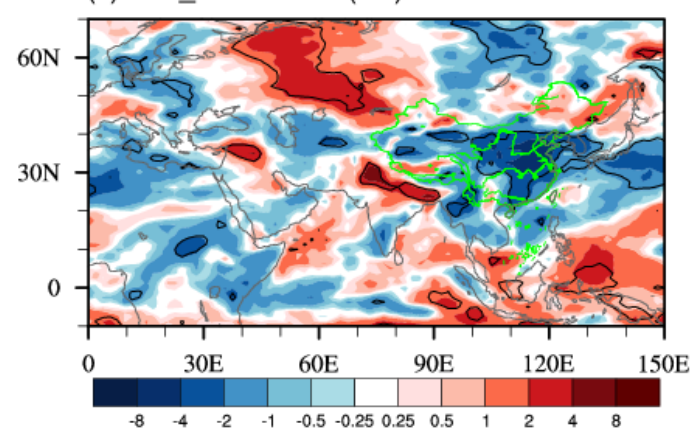

(e) DJF_LH (AA)

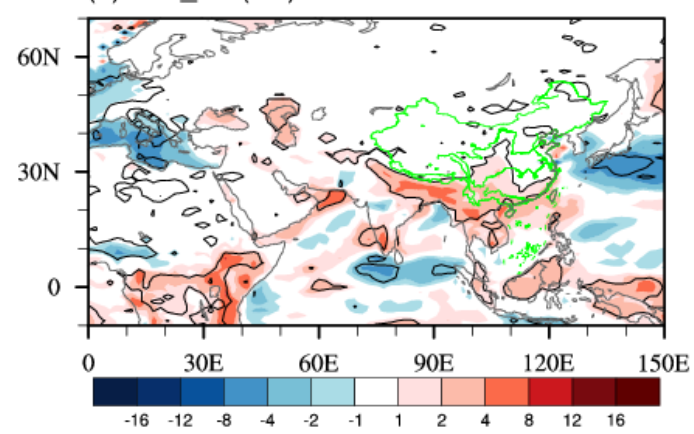

(b) DJF_Water vapor (AA)

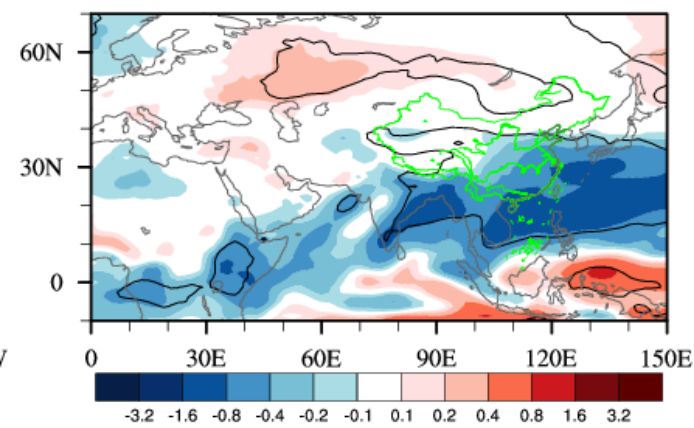

(d) DJF_SW CRE (AA)

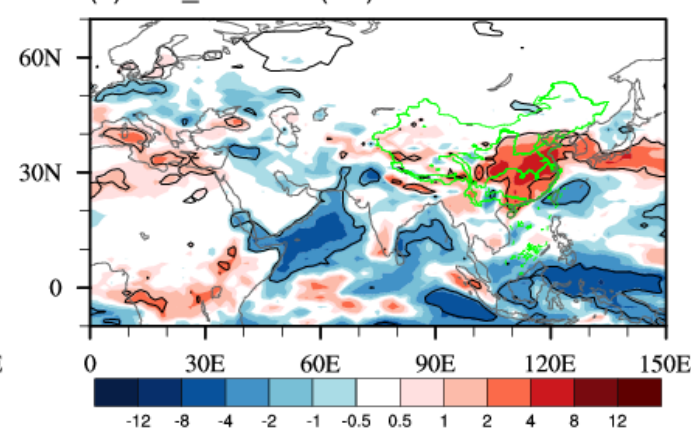

(f) DJF_Evaporation (AA)

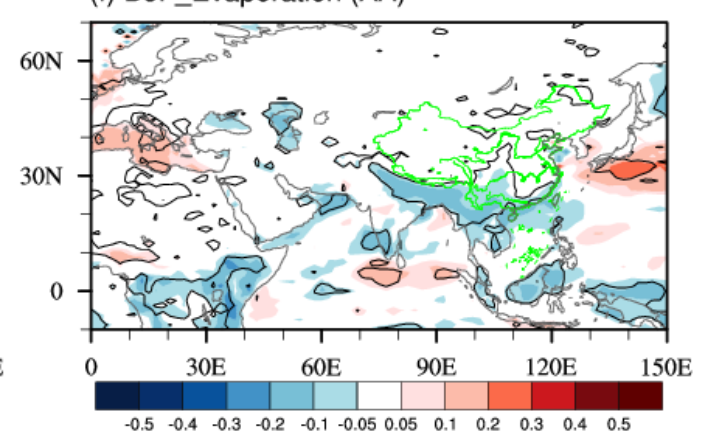

Figure 10. Spatial patterns of winter mean response to changes in AA forcing: (a) skin temperature (units: ${ }^{\circ} \mathrm{C}$ ); (b) column-integrated water vapor (units: $\mathrm{kg} \mathrm{m}^{-2}$ ); (c) total cloud cover (units: \%); (d) SW CRE; (e) surface latent hear flux; and (f) evaporation (units: $\mathrm{kg} \mathrm{m}^{-2}$ ). Radiation and flux are in $\mathrm{W} \mathrm{m}^{-2}$ with positive value meaning downward. The black lines highlight regions where the changes are statistically significant at the $90 \%$ confidence level base on $t$-test. 